\title{
Metagenomic community composition and resistome analysis in a full-scale cold climate wastewater treatment plant
}

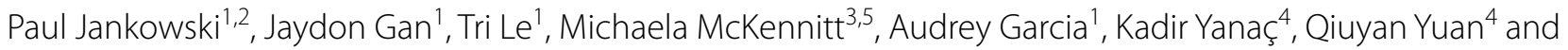
Miguel Uyaguari-Diaz ${ }^{1 *}$ (i)

\begin{abstract}
Background: Wastewater treatment plants are an essential part of maintaining the health and safety of the general public. However, they are also an anthropogenic source of antibiotic resistance genes. In this study, we characterized the resistome, the distribution of classes 1-3 integron-integrase genes (int/1, int/2, and int/3) as mobile genetic element biomarkers, and the bacterial and phage community compositions in the North End Sewage Treatment Plant in Winnipeg, Manitoba. Samples were collected from raw sewage, returned activated sludge, final effluent, and dewatered sludge. A total of 28 bacterial and viral metagenomes were sequenced over two seasons, fall and winter. Integron-integrase genes, the $16 \mathrm{~S}$ rRNA gene, and the coliform beta-glucuronidase gene were also quantified during this time period.
\end{abstract}

Results: Bacterial classes observed above $1 \%$ relative abundance in all treatments were Actinobacteria $(39.24 \% \pm 0.25 \%)$, Beta-proteobacteria (23.99\% $\pm 0.16 \%)$, Gamma-proteobacteria (11.06\% $\pm 0.09 \%)$, and Alphaproteobacteria $(9.18 \pm 0.04 \%)$. Families within the Caudovirales order: Siphoviridae (48.69\% $\pm 0.10 \%)$, Podoviridae $(23.99 \% \pm 0.07 \%)$, and Myoviridae (19.94\% $\pm 0.09 \%)$ were the dominant phage observed throughout the NESTP. The most abundant bacterial genera (in terms of average percent relative abundance) in influent, returned activated sludge, final effluent, and sludge, respectively, includes Mycobacterium (37.4\%, $18.3 \%, 46.1 \%$, and $7.7 \%)$, Acidovorax $(8.9 \%, 10.8 \%, 5.4 \%$, and $1.3 \%)$, and Polaromonas $(2.5 \%, 3.3 \%, 1.4 \%$, and $0.4 \%)$. The most abundant class of antibiotic resistance in bacterial samples was tetracycline resistance $(17.86 \% \pm 0.03 \%)$ followed by peptide antibiotics $(14.24 \% \pm 0.03 \%)$, and macrolides (10.63\% $\pm 0.02 \%)$. Similarly, the phage samples contained a higher prevalence of macrolide $(30.12 \% \pm 0.30 \%)$, peptide antibiotic $(10.78 \% \pm 0.13 \%)$, and tetracycline $(8.69 \% \pm 0.11 \%)$ resistance. In addition, int/1 was the most abundant integron-integrase gene throughout treatment $\left(1.14 \times 10^{4}\right.$ gene copies $\left./ \mathrm{mL}\right)$ followed by int $13\left(4.97 \times 10^{3}\right.$ gene copies $\left./ \mathrm{mL}\right)$ while int $/ 2$ abundance remained low $\left(6.4 \times 10^{1}\right.$ gene copies $\left./ \mathrm{mL}\right)$.

Conclusions: Wastewater treatment successfully reduced the abundance of bacteria, DNA phage and antibiotic resistance genes although many antibiotic resistance genes remained in effluent and biosolids. The presence of integron-integrase genes throughout treatment and in effluent suggests that antibiotic resistance genes could be actively disseminating resistance between both environmental and pathogenic bacteria.

*Correspondence: Miguel.Uyaguari@umanitoba.ca

1 Department of Microbiology, University of Manitoba, 45 Chancellors

Circle, Buller Building, Winnipeg, MB R3T 2N2, Canada

Full list of author information is available at the end of the article permits use, sharing, adaptation, distribution and reproduction in any medium or format, as long as you give appropriate credit to the original author(s) and the source, provide a link to the Creative Commons licence, and indicate if changes were made. The images or other third party material in this article are included in the article's Creative Commons licence, unless indicated otherwise in a credit line to the material. If material is not included in the article's Creative Commons licence and your intended use is not permitted by statutory regulation or exceeds the permitted use, you will need to obtain permission directly from the copyright holder. To view a copy of this licence, visit http://creativecommons.org/licenses/by/4.0/. The Creative Commons Public Domain Dedication waiver (http://creativeco mmons.org/publicdomain/zero/1.0/) applies to the data made available in this article, unless otherwise stated in a credit line to the data. 
Keywords: Antibiotic resistance genes, Wastewater treatment, Metagenomics, Resistome, Integrases, Bacterial community, Bacteriophages

\section{Background}

Wastewater treatment plants (WWTPs) are essential to maintain quality of life by protecting public health and aquatic organisms. They serve as a centralized system that collects wastewater for large-scale treatment to reduce the contamination of downstream aquatic environments. Wastewater treatment consists of removing nutrients, solids, and microbial biomass, which is critical in reducing the impact of releasing wastewater into the environment $[1,2]$. However, these water infrastructures were not designed to efficiently remove all chemical and biological pollutants. Specifically, WWTPs have been shown to contain diverse communities of environmental and pathogenic bacteria as well as antibiotics, pharmaceutical products, and heavy metals that remain throughout the treatment processes [2-4]. Although chemical pollutants in wastewater such as antibiotics and their metabolites are found in lower and potentially subinhibitory concentrations ranging from 0.1 to $1.4 \mathrm{ppb}$ [5-7], their presence is concerning given their potential role as a selective pressure for the exchange of resistance genes $[3,8]$.

The large diversity and abundance of bacteria within wastewater combined with selective pressures from antibiotics and disinfectants creates a hotspot for the development and transfer of antibiotic resistance between bacteria $[9,10]$. Mobile genetic elements (MGE) such as plasmids, transposons, and integrons are well characterized genetic elements important for the transfer of antibiotic resistance genes (ARGs) by conjugation and transformation $[8,10]$. Phages, viruses that infect bacteria, have recently gained attention as another source of ARGs that can transfer resistance through transduction $[11,12]$. Phages are the most abundant biological entity within any given environment with an estimated abundance of $10^{31}$ viruses worldwide [13, 14]. We are only beginning to characterize and recognize the importance of this diversity, not only as a source of new genes, but also as a pool of ARGs accessible by bacteria [11, 12, 15]. As a major link between society and the environment, WWTPs receive sewage water from many sources including households, hospitals, and industry. This represents an ideal environment for the transfer of ARGs between bacteria and from phages to bacteria. This poses concerns about the accumulation of antibiotic resistance and the potential to transfer ARGs to clinically relevant pathogens that may be present within wastewater [16]. As antibiotic resistance accumulates both clinically and in the environment, we continue to descend towards a post-antibiotic era with antibiotics becoming less effective and viable as a therapeutic option for treating bacterial infections [16, 17]. To prevent this loss of antibiotic effectiveness, it is imperative that we mitigate the spread of antibiotic resistance by reducing opportunities for horizontal gene transfer [18]. These strategies include both clinical and environmental considerations to curtail ARG dissemination. Recent advancements along with the reduction in cost of high-throughput culture-independent methods such as next-generation sequencing have improved our ability to monitor ARG dissemination [19-21].

In the present study, we use metagenomic shotgun sequencing and real-time PCR to characterize the composition of both bacteria and phage diversity as well as the resistome of major treatment processes within the North End Sewage Treatment Plant (NESTP) located in Winnipeg, Manitoba, Canada during the fall and winter months. This study serves as a baseline for the continued monitoring of ARG dissemination over each season, which will contribute to our understanding of antibiotic resistance and community structures within various wastewater treatment processes. This information is essential for future large-scale upgrades of the NESTP targeting phosphorus and nitrogen removal as well as microbiological changes occurring within WWTPs. This will enable us to monitor the effects of modifying operational parameters on microbial diversity and the resistome as well as introduce modifications to the process aimed at reducing the release of ARGs and antibiotic resistant bacteria into the aquatic environment.

\section{Materials and methods WWTP processing and sample collection}

The NESTP is the largest wastewater facility in the Province of Manitoba $\left(49^{\circ} 57^{\prime} 08.1^{\prime \prime} \mathrm{N} 97^{\circ} 06^{\prime} 11.4^{\prime \prime} \mathrm{W}\right)$ operating year-round with seasonal temperatures ranging from -40 to $30^{\circ} \mathrm{C}$ with the current study ranging from -18.6 to $2.8{ }^{\circ} \mathrm{C}$. This WWTP serves roughly $70 \%$ of the population in the city of Winnipeg treating an average of 200 million liters per day. Treatment begins with the removal of large solids followed by smaller solids and oils in primary clarification. Wastewater is then moved to high purity oxygen bioreactors for biological treatment where it is inoculated with activated sludge returned from secondary clarification to remove nutrients, biosolids, and other organic compounds. This is followed by secondary 
clarification which removes the remaining small solids through sedimentation before the wastewater is subjected to UV disinfection. The total hydraulic retention time of wastewater in the NESTP is $12 \mathrm{~h}$. The removed biosolid waste is subjected to anaerobic sludge digestion for 25 days followed by dewatering for disposal. UVtreated final effluent water quality parameters are summarized in Table 1 . Influent and effluent water quality datasets are included in Additional file 2. Raw sewage or untreated influent (RS), returned activated sludge (RAS), and UV-treated final effluent (EFF) were collected on the following dates from the NESTP: October 22nd, 2019 (T1), November 28th, 2019 (T2), December 18th, 2019 (T3), and February 6th, 2020 (T4). Dewatered sludge (SC) was also collected during the T3 and T4 sampling events. One liter of each sample was collected in sterile containers and transported on ice to the laboratory where they were stored at $4{ }^{\circ} \mathrm{C}$. Within $24 \mathrm{~h}$ of collection, aqueous treatment samples were filtered through a sterile cheesecloth to remove large solids and 100 to $200 \mathrm{~mL}$ of the filtrate was filtered through $0.2-\mu \mathrm{m} 47-\mathrm{mm}$ Supor200 membrane filters (Pall Corporation, Ann Harbor, MI) to capture bacterial cells for nucleic acid extraction. A filtration control consisting of $200 \mathrm{~mL}$ of Milli-Q water was also prepared for each sampling event. Filters were collected and stored at $-20^{\circ} \mathrm{C}$ for further processing.

\section{Bacterial fraction DNA extraction}

For the aqueous treatment samples (RS, RAS, and EFF), the $0.2-\mu \mathrm{m}$ filters were washed with $15 \mathrm{~mL}$ of $1 \times$ PBSTween 20 solution and homogenized at $2500 \mathrm{rpm}$ for $15 \mathrm{~min}$. Supernatants were then transferred to a fresh tube and centrifuged at $3300 \times g$ for 15 min to pellet down cells. Pellet was resuspended and transferred to PowerBead tubes for nucleic acid extraction using the DNeasy PowerLyzer PowerSoil Kit (Qiagen Sciences, Maryland, $\mathrm{MD)}$ as per the manufacturer's instructions. For the dewatered sludge samples, 5 g of solids was collected into $30 \mathrm{~mL}$ of $1 \times$ PBS-Tween 20 solution, vortexed until homogeneous ( $2500 \mathrm{rpm}$ for $15 \mathrm{~min}$ ) and centrifuged at $4{ }^{\circ} \mathrm{C}$ and $4500 \times g$ for $20 \mathrm{~min}$. The resulting pellet $(0.25 \mathrm{~g})$ was then transferred to a PowerBead tube and extracted using the DNeasy PowerLyzer PowerSoil kit as per the manufacturer's instructions, while the supernatant was kept for further filtration and DNA extraction of viral particles.

\section{Viral fraction DNA extraction}

The $0.2-\mu \mathrm{m}$ filter flow-through from the aqueous treatment samples was collected and stored at $4{ }^{\circ} \mathrm{C}$. Dewatered sludge viral DNA extraction followed the bacterial DNA extraction protocol scaled up to $30 \mathrm{~g}$ followed by supernatant filtration through $0.2-\mu \mathrm{m}$ filter repeated twice. For both sets of samples, $140 \mathrm{~mL}$ of filtrate was transferred into Centricon Plus-70 filter units (Millipore Corporation, Billerica, MA). Filtrates were concentrated to $\sim 250 \mu \mathrm{L}$ according to the manufacturer's instructions with additional modifications described here. Each sample was centrifuged at $3000 \times g$ for $30 \mathrm{~min}$ at $20^{\circ} \mathrm{C}$ in $70 \mathrm{~mL}$ increments. The supernatant was discarded after each run. The Centricon Plus70 filter units were then inverted, and the concentrated viral fraction was transferred to sterile tubes and centrifuged at $800 \times g$ for $2 \mathrm{~min}$ at $20^{\circ} \mathrm{C}$. The ultrafiltrate

Table 1 UV-treated final effluent water quality parameters of the North End Sewage Treatment Plant

\begin{tabular}{|c|c|c|c|c|c|c|}
\hline & \multicolumn{4}{|l|}{ Sampling time } & \multirow[t]{2}{*}{ Mean } & \multirow{2}{*}{$\begin{array}{l}\text { Standard } \\
\text { deviation }\end{array}$} \\
\hline & Oct-22-2019 (T1) & $\begin{array}{l}\text { Nov-28-2019 } \\
\text { (T2) }\end{array}$ & $\begin{array}{l}\text { Dec-18-2019 } \\
\text { (T3) }\end{array}$ & Feb-6-2020 (T4) ${ }^{\ddagger}$ & & \\
\hline $\mathrm{pH}$ & 7.12 & 6.81 & 6.79 & 6.99 & 6.93 & 0.14 \\
\hline Turbidity (NTU) & $12.25^{\dagger}$ & 4.2 & 6.3 & 9.2 & 7.99 & 3.03 \\
\hline TSS (mg/L) & $19.5^{\dagger}$ & 6 & 10 & 18 & 13.38 & 5.58 \\
\hline $\mathrm{BOD}(\mathrm{mg} / \mathrm{L})$ & $19.5^{\dagger}$ & 13 & 18 & 26 & 19.13 & 4.64 \\
\hline COD (mg/L) & $51.5^{\dagger}$ & 66 & 94 & 89 & 75.13 & 17.25 \\
\hline $\mathrm{TN}(\mathrm{mg} / \mathrm{L})$ & $15.4^{\dagger}$ & 40.7 & 49.8 & 50.5 & 39.1 & 14.22 \\
\hline $\mathrm{TP}(\mathrm{mg} / \mathrm{L})$ & $1.67^{\dagger}$ & 3.43 & 1.69 & 1.69 & 2.12 & 0.76 \\
\hline $\mathrm{TOC}(\mathrm{mg} / \mathrm{L})$ & $19.8^{\dagger}$ & 21.2 & 29.6 & 34.4 & 26.25 & 6.02 \\
\hline Precipitation $(\mathrm{mm})^{*}$ & 4.8 & 0 & 1 & 1.6 & 1.85 & 1.8 \\
\hline Grab temperature $\left({ }^{\circ} \mathrm{C}\right)$ & 13.4 & 14.1 & 14.1 & 12.7 & 13.6 & 0.7 \\
\hline E. coli (counts/100 mL) & 60 & 60 & 90 & 1080 & 322.5 & 437.51 \\
\hline
\end{tabular}

TSS, total suspended solids; BOD, biochemical oxygen demand; COD, chemical oxygen demand; TN, total nitrogen; TP, total phosphorus; TOC, total organic carbon

*Cumulative amount of rainfall over three days

${ }^{\dagger}$ Parameters measured the day before and the day after were averaged and used to estimate parameters of sample date 
was pre-treated with $2 \mathrm{U}$ of Turbo DNase and $60 \mu \mathrm{g}$ of RNAse A (ThermoFisher Scientific, Waltham, MA, USA). Nucleic acid was extracted using the QIAamp MinElute Virus Spin kit (Qiagen Sciences, Maryland, $\mathrm{MD})$ following the manufacturer's instructions including the Qiagen Protease and omitting the carrier RNA step. Nucleic acid was eluted with $50 \mu \mathrm{L}$ of AVE elution buffer.

\section{Mock community}

Positive sequencing controls were created for each bacterial and viral sequencing batch. Bacterial mock community consisted of equal amounts of Escherichia coli (ATCC 25922), Salmonella enterica (ATCC 13076), Pseudomonas aeruginosa (ATCC 10145), Staphylococcus aureus (ATCC 25923), Legionella pneumophila (ATCC 33152), L. longbeachae, clinical isolates of Campylobacter lari and C. upsaliensis, and environmental isolates of $C$. jejuni and C. coli with a total concentration of $11.2 \mathrm{ng} / \mu \mathrm{L}$. The viral mock community consisted of equal amounts of Adenovirus and Myophages M2 and M3 with a total concentration of $0.4 \mathrm{ng} / \mu \mathrm{L}$. Nucleic acid was extracted from the bacterial mock community using the DNeasy PowerLyzer PowerSoil Kit (Qiagen Sciences, Maryland, MD) according to the manufacturer's instructions. Viral mock community nucleic acid was extracted using the QIAamp MinElute Virus Spin kit (Qiagen Sciences, Maryland, MD) including the modifications described above (see Methods: "Viral fraction DNA extraction" section).

\section{DNA precipitation and sequencing}

All extracted bacterial DNA samples were precipitated using 0.1 volumes of $3 \mathrm{M}$ sodium acetate $(\mathrm{pH} 4.6)$, two volumes of $100 \%$ ethanol, and $4 \mu \mathrm{L}$ of $5 \mathrm{mg} / \mathrm{mL}$ linear acrylamide, which was stored at $-80{ }^{\circ} \mathrm{C}$ overnight. Samples were centrifuged at $16,000 \times g$ for $30 \mathrm{~min}$ at $4{ }^{\circ} \mathrm{C}$. Supernatants were discarded and pellets were washed with $1 \mathrm{~mL}$ of ice-cold $70 \%$ ethanol before repeating centrifugation. Resulting pellets were air-dried and resuspended in $50 \mu \mathrm{L}$ of $10 \mathrm{mM}$ Tris solution. DNA concentration was measured using the Qubit 4.0 fluorometer and Qubit dsDNA High Sensitivity Assay Kit (Invitrogen, Carlsbad, CA). Metagenomic shotgun sequencing was performed on the Illumina NextSeq platform (Illumina, Inc., San Diego, CA) at $1 \times$ depth using the Illumina Nextera Flex kit with 300 bp paired-end outputs at the Integrated Microbiome Resource (IMR, Halifax, NS). Raw sequencing read adaptor sequences were trimmed prior to receiving sequencing reads. Raw metagenomic sequencing reads are available in the NCBI Sequence Read Archive under BioProject ID: 768945.

\section{Quantification of gene copy numbers and statistical analysis}

Real-time PCR TaqMan assays were carried out for each sample (RS, RAS, EFF, and the negative filter control) in triplicate. Mobile integron-integrase genes (classes 1-3) served as biomarkers for measuring variation in ARG dissemination between treatments $[8,22]$. Coliform betaglucuronidase gene uidA was used as a culture-independent method of $E$. coli and coliform quantification [23] in addition to plate counts reported in Table 1. The $16 \mathrm{~S}$ rRNA gene was quantified to assess total bacterial abundance. Sequence and product size of primers and probes are listed in Table 2. Real-time PCR data for the dewatered sludge was unavailable for the present study.

Each $10 \mu \mathrm{L}$ TaqMan real-time PCR mixture consisted of $5 \mu \mathrm{L}$ of TaqMan Environmental Master Mix 2.0 (Applied Biosystems, Foster City, CA), $400 \mathrm{nM}$ of each primer, $100 \mathrm{nM}$ of each probe, and $2 \mu \mathrm{L}$ of $10 \mathrm{ng} /$ $\mu \mathrm{L}$ template DNA. Real-time PCR was performed using an ABI QuantStudio 5 Real-Time PCR System (Applied Biosystems, Foster City, CA). Thermal cycling conditions were the same for all targeted genes: 2 min incubation at $50^{\circ} \mathrm{C}$, denaturation and activation of Taq polymerase for $10 \mathrm{~min}$ at $95^{\circ} \mathrm{C}$, followed by 40 cycles of $15 \mathrm{~s}$ at $95^{\circ} \mathrm{C}$ and $60 \mathrm{~s}$ at $60^{\circ} \mathrm{C}$. Primers and probes are listed in Table 2. Primers were used in the Primer-BLAST tool [24] to extract target regions. Then, these regions were uploaded to Geneious Prime R9 [25] to corroborate primer and probe sequences of gene fragments. Combined integron-integrase gene primer sequences and uidA primer sequences were used to construct gBlock Gene Fragments (IDT, Coralville, IA). These gBlock constructs were used to generate standard curves for the quantification of environmental gene copy numbers (GCN).

The 16S rRNA gene standard curve was generated with DNA from Salmonella enterica (ATCC 13076). GCN of all target genes were calculated and normalized per milliliter of sample filtered and per nanogram of DNA using equations described by Ritalahti et al. [26] and Lee et al. [27]. GCN were $\log _{10}$-transformed for generalized linear model (GLM) analysis using Statistical Analysis System (SAS University Edition for Windows). TukeyKramer tests were run to determine statistical differences between GCN using GLM results for treatment conditions and across sampling events (T1 through T4) [28]. Differences between conditions were considered statistically significant at a $\mathrm{p}$-value $\leq 0.05$.

\section{Metagenomic data processing and analysis}

Taxonomical characterisation. Raw metagenomic shotgun sequencing reads were processed in Geneious (version 9.0.5) by pairing and merging paired-end 
Table 2 Description of primers and probes used for quantitative PCR

\begin{tabular}{|c|c|c|c|c|}
\hline Gene & Primer name & Sequence $\left(5^{\prime}-3^{\prime}\right)$ & Product size (bp) & References \\
\hline \multirow[t]{3}{*}{ int17 } & Intl1-LC1 & GCCTTGATGTTACCCGAGAG & & Barraud et al. [22] \\
\hline & Intl1_LC5 & GATCGGTCGAATGCGTGT & 196 & \\
\hline & Intl1_probe & (FAM) ATTCCTGGCCGTGGTTCTGGGTTTT (/ZEN, IABkFQ) & & \\
\hline \multirow[t]{3}{*}{ int 12} & Int|2_LC2 & TGCTTTTCCCACCCTTACC & & Barraud et al. [22] \\
\hline & Int12_LC3 & GACGGCTACCCTCTGTTATCTC & 195 & \\
\hline & Intl2_probe & FAM-TGGATACTCGCAACCAAGTTATTTTTACGCTG (/ZEN, IABkFQ) & & \\
\hline \multirow[t]{3}{*}{ int 13} & Intl3_LC1 & GCCACCACTTGTTTGAGGA & & Barraud et al. [22] \\
\hline & Intl3_LC2 & GGATGTCTGTGCCTGCTTG & 138 & \\
\hline & Intl3_probe & (FAM) CGCCACTCATTCGCCACCCA (/ZEN, IABkFQ) & & \\
\hline \multirow[t]{3}{*}{ uidA } & $784 \mathrm{~F}$ & GTGTGATATCTACCCGCTTCGC & & Frahm and Obst [23. \\
\hline & $866 \mathrm{R}$ & AGAACGGTTTGTGGTTAATCAGGA & 84 & \\
\hline & EC807 & (FAM) TCGGCATCCGGTCAGTGGCAGT (/ZEN, IABkFQ) & & \\
\hline \multirow[t]{3}{*}{16 s rRNA gene } & Bac1055YF & ATGGYTGTCGTCAGCT & & Ritalahti et al. [26] \\
\hline & Bac1392R & ACGGGCGGTGTGTAC & $\sim 320 \mathrm{bp}$ & \\
\hline & Bac1115P & (FAM) CAACGAGCGCAACCC (/ZEN, IABkFQ) & & \\
\hline
\end{tabular}

reads before filtering sequence lengths below $151 \mathrm{bp}$ to remove short and low-quality reads [29]. These reads were then used as input for MG-RAST to characterize the community composition through sequence similarity searches using default parameters [30]. Metagenomic sequences are available from MG-RAST with sequence IDs listed in Additional file 1: Table S1. Principal coordinate analysis (PCoA) with Bray-Curtis distance matrix was performed using abundance data at the species taxonomic level using the phyloseq $\mathrm{R}$ package [31]. Alpha-diversity indices (Shannon diversity, Simpson diversity, and Chao1) and rarefaction curves were generated using vegan $R$ package [32]. Data visualization was performed using Tableau [33] and ggplot2 [34] in RStudio [35]. Alpha-diversity values were $\log _{10}$-transformed for generalized linear model (GLM) analysis and Tukey-Kramer test using SAS 9.4M6 to determine statistical differences between treatments [28].

ARG analysis. The merged and filtered paired-end reads were used to generate contigs with the Geneious (version 9.0.5) de novo assembler tool at medium-fast sensitivity using default settings $[25,29]$. The contigs (range $151 \mathrm{bp}$ to $197 \mathrm{~kb}$ ) were then compared against the comprehensive antibiotic resistance database (CARD) using the resistance gene identifier tool (RGI) to identify ARGs for the characterization of the resistome [36]. The ARGs identified by CARD RGI were grouped into classes according to the type of antibiotic they confer resistance against and quantified by absolute abundance as well as relative abundance (number of ARG class divided by total ARG) and normalized abundance (number of ARG class divided by the total number of bacterial and viral reads) reported in percentage.

Network analysis and visualization. Network analysis was performed to investigate co-occurrences between ARGs and bacterial and phage families in the different wastewater sample types. Microsoft Excel was used to organize data into a suitable format for R [37]. RStudio [35], was used to generate Spearman's correlation matrices and the preliminary edge and node lists needed for network visualization. The $\mathrm{R}$ packages used are listed in Additional file 1: Table S2. The edge and node lists were finalized using Microsoft Excel. Gephi [38] was then utilized for network visualization. Gephi's output files were aesthetically enhanced in Inkscape [39].

\section{Results and discussion}

Taxonomical composition of the North End Sewage Treatment Plant

Bacterial community composition

The major bacterial classes found in almost all samples above $1 \%$ relative abundance were Actinobacteria $(39.24 \% \pm 0.25 \%)$, Betaproteobacteria $(23.99 \% \pm 0.16 \%)$, Gammaproteobacteria (11.06\% $\pm 0.09 \%)$, Alphaproteobacteria $(9.18 \pm 0.04 \%)$, and Bacteroidia $(2.63 \% \pm 0.02 \%)$. This is consistent with other reports of WWTP class composition [40-42]. PCoA (Fig. 1) and relative abundance comparisons (Fig. 2a) were performed to determine the relatedness of samples and fractions across treatments and sampling events. Bacteria PCoA (Fig. 1a) shows clustering of the RS, RAS, and EFF samples together by treatment and by month. SC samples were more similar to each other but clustered away suggesting compositional differences after anaerobic digestion 

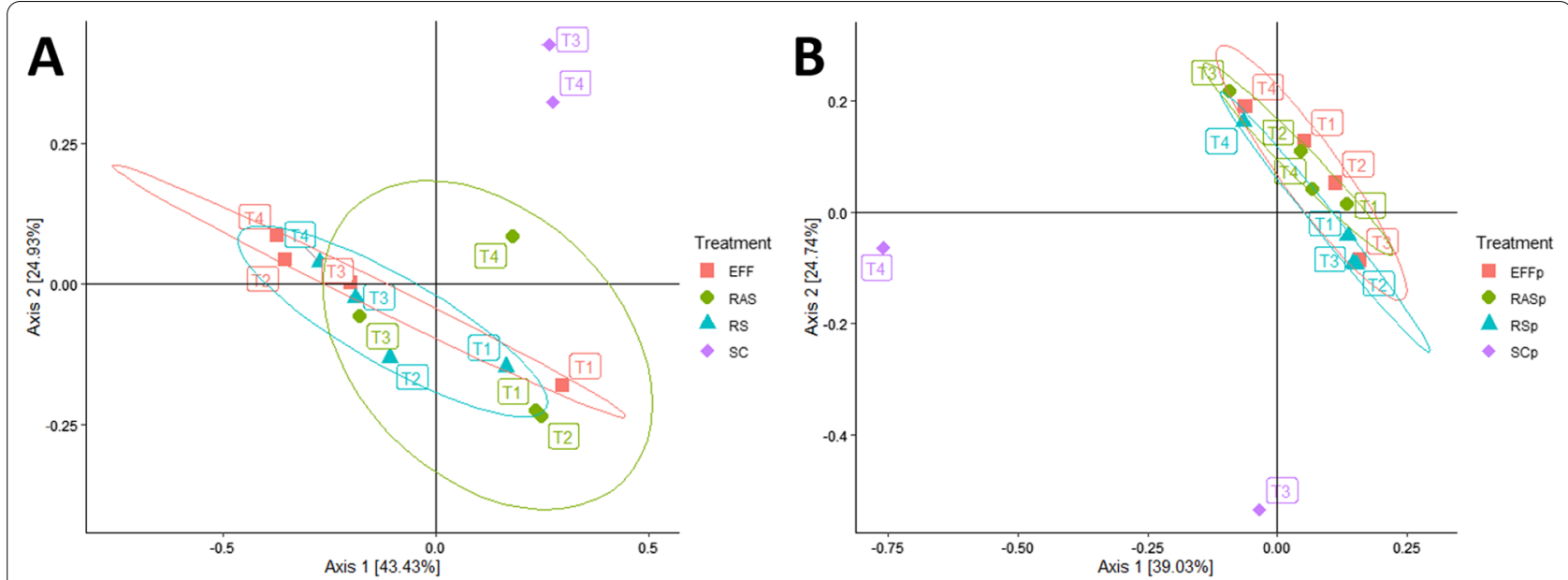

Fig. 1 Principal coordinates analysis across treatments using the Bray-Curtis distance matrix at the species level. A Comparison of the bacterial samples stratified by domain, principal components 1 and 2 explain $68.36 \%$ of the variation. B Comparison of the phage samples stratified by domain, principal components 1 and 2 explain $63.77 \%$ of the variation. Effluent (EFF), returned activated sludge (RAS), raw sewage/influent (RS), dewatered sludge (SC), negative control (NEG), October (T1), November (T2), December (T3), February (T4), notation of "p" indicates phage sample
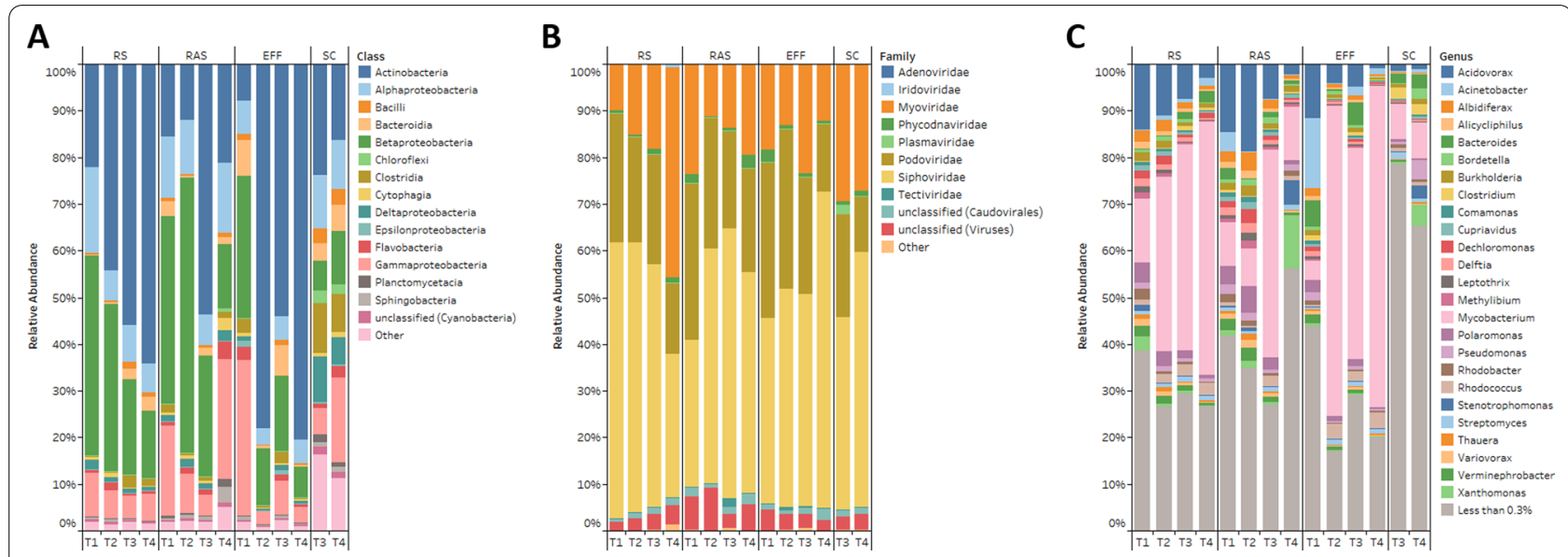

Fig. 2 Composition of bacteria and phage in the North End Sewage Treatment Plant. A Relative abundance of bacteria at the class level. B Relative abundance of phage at the family level. C Relative abundance of bacteria at the genus level. Effluent (EFF), returned activated sludge (RAS), raw sewage/influent (RS), negative control (NEG), October (T1), November (T2), December (T3), February (T4)

and the dewatering process. Indeed, SC had significantly higher diversity that was more evenly distributed compared to EFF by Shannon $(\mathrm{p}=0.02)$ and Simpson diversity indices $(p=0.01)$ (Fig. 3a and $b)$. SC also had higher diversity compared to RS and RAS, but this was not significant. Additionally, the relative abundance of bacterial classes in the SC samples appeared to be more evenly distributed than the other sample types (Fig. 2a). The Chao1 diversity index showed similar richness across treatments with no significant differences detected (Fig. 3c). Each sampling event also displayed differences in clustering with the samples from $\mathrm{T} 1$ and $\mathrm{T} 3$ clustering closely together while $\mathrm{T} 2$ and $\mathrm{T} 4$ separated across the $\mathrm{x}$-axis (Fig. 1a). A potential explanation for this grouping is the fluctuation in the relative abundance of Actinobacteria, Beta-proteobacteria, and Gamma-proteobacteria across samples for both T2 and T4 (Fig. 2a). This suggests that there were shifts in the relative dominance of certain classes of bacteria over the course of treatment during these two time points. Curiously, the negative controls for T1 and T2 sampling events had similar alpha-diversity scores for both Shannon and Simpson diversity, yet a lower score for Chao1 was recorded (Fig. 3). Inspection of the genus dataset (see Additional file 2) and relative 

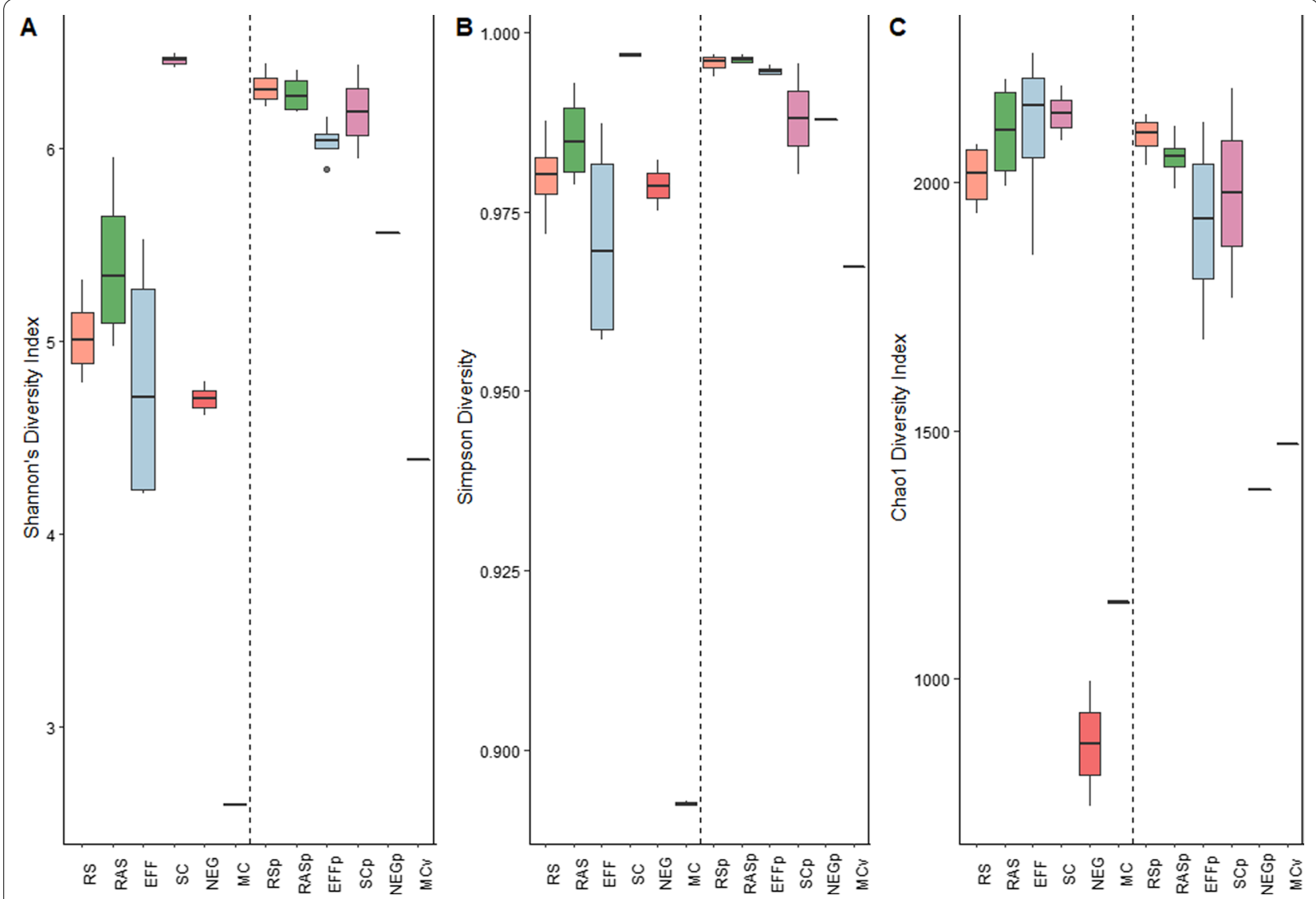

Fig. 3 Alpha diversity indices of each treatment at the species level. A Shannon's diversity index. B Simpson diversity index. C Chao1 index

abundances (Additional file 1: Figure S2a) reveals that most of the represented genera in the negative controls match previously reported genera found in the kitome suggesting contamination related to the DNA extraction kit [43]. The presence of kitome contaminants in T3 and T4 negative controls could not be evaluated due to insufficient number of reads for analysis in MG-RAST (Additional file 1: Table S1).

The bacterial community composition at the genus level for RS, RAS, EFF, and SC for each sampling event is displayed in Fig. 2c. Average percent relative abundance in RS, RAS, EFF, and SC respectively, consisted of, but was not limited to, Mycobacterium (37.4\%, 18.3\%, 46.1\%, and 7.7\%), Acidovorax (8.9\%, 10.8\%, 5.4\%, and $1.3 \%)$, Polaromonas (2.5\%, 3.3\%, $1.4 \%$, and $0.4 \%)$, Acinetobacter $(0.9 \%, 1.2 \%, 4.6 \%$, and $0.5 \%)$, Xanthomonas (1.1\%, 3.7\%, 0.3\%, and 2.4\%), Bacteroides (1.1\%, 1.1\%, $2.7 \%$, and $2.4 \%)$, Albidiferax (1.8\%, 2.1\%, $0.9 \%$, and $0.3 \%$ ), Rhodococcus (2.0\%, 1.1\%, 2.2\%, and 0.9\%), Verminephrobacter $(1.4 \%, 1.7 \%, 0.9 \%$, and $0.2 \%)$, and Pseudomonas $(0.9 \%, 1.4 \%, 0.8 \%$, and $2.4 \%)$. Nitrospira, a common genus contributing to nitrite oxidation typically found in high abundance (around 2\% to 6\%) in WTTPs [44-47] had an average abundance of $0.06 \%$ in the NESTP. Acidovorax, Pseudomonas, and Xanthomonas have previously been reported as being highly abundant in activated sludge as common denitrifying bacteria [48-50]. Interestingly, Polaromonas, a psychrophile most abundant on glacier surfaces, was found to have a high relative abundance throughout wastewater treatment $[51,52]$. The presence of Polaromonas suggests that it could potentially play a role in biochemical cycling in the cold climate found during winter in Manitoba [51, 53]. Mycobacterium was the most abundant genus throughout treatment apart from the SC samples where genera were more evenly distributed (Figs. 2c, 3b). This trend was also observed through real-time PCR by Amha et al. where the relative abundance of non-tuberculoid Mycobacterium species in wastewater increased after chlorine treatment [54]. These results may be explained by the ability of Mycobacterium species to aggregate together in aquatic environments. Bohrerova and Linden demonstrated that increasing aggregate sizes of $M$. terrae were able to better survive UV inactivation compared to non-aggregated 
samples [55]. The composition of bacteria in RAS was different from several reports of activated sludge composition sharing only a few genera in common [44-46, $48,49,51]$. The bacterial mock community provides support for the presence of the genera observed as all of the spiked-in species were represented at the genus level with high relative abundance (Additional file 1: Figure S2b). Although there was a high amount of richness observed in the mock community (Fig. 3c), this could be explained by possible kitome contamination during extraction [43] as well as the use of a large number of reads and default MG-RAST annotation parameters during annotation resulting in inflated richness $[56,57]$.

The ESKAPE group (consisting of Enterococcus faecium, Staphylococcus aureus, Klebsiella pneumoniae, Acinetobacter baumannii, Pseudomonas aeruginosa, and Enterobacter spp. [58]) of nosocomial pathogens are a major issue causing both clinical and economic burden across the world due to their propensity to develop multidrug resistance against virtually all available antimicrobial agents [59]. Although resistance often develops through person-person transmission and misuse of antimicrobials, environments such as wastewater represent an additional milieu for the transfer of MGEs between environmental and pathogenic bacteria [16, 17]. In fact, the ESKAPE group has been detected in effluent [60] and dewatered sludge in the current study. All representatives of this group were detected across all sampling sites and sampling events (see Additional file 2). This suggests that MGEs carrying ARGs may not only be transferred to other bacteria, but to these nosocomial pathogens as well. Although we cannot detect whether ARGs were obtained by this group, their presence in this selective environment is concerning given the potential to acquire resistance. Furthermore, the release of these pathogens in downstream aquatic environments and in dewatered sludge, often used as agricultural fertilizer, poses the risk of reintroducing these pathogens into anthropogenic settings where they can further endanger public health [41, 61].

\section{Composition of the NESTP phageome}

Taxonomic identification of the DNA phages was completed with MG-RAST and the composition of the phageome is reported at the family taxonomic level in Fig. 2b. The most abundant phages within the NESTP phageome belong to the tailed dsDNA phages within the order Caudovirales. Siphoviridae was the most abundant family with a relative abundance of $48.69 \% \pm 0.10 \%$ across all samples followed by Podoviridae $(23.99 \% \pm 0.07 \%)$, Myoviridae $(19.94 \% \pm 0.09 \%)$, and unclassified Caudovirales $(1.47 \% \pm 0.01 \%)$. These phages comprise the majority of DNA phages found in the NESTP (Fig. 2b). This is in accordance with metagenomic studies of phages in wastewater [62-64] as well as in a freshwater ecosystem [65]. Members of the Caudovirales order infect many of the genera present in the NESTP including Mycobacterium, Acinetobacter, Pseudomonas, Salmonella, Escherichia, and Staphylococcus $[63,66]$. Other viruses identified were Phycodnaviridae $(1.08 \% \pm 0.01 \%)$ and Tectiviridae $(0.27 \% \pm 0.01 \%)$. Neither of these low abundance viruses were detected in the negative control suggesting that they were likely present within the NESTP (Additional file 1: Figure S2c; see Additional file 2). Additionally, the taxonomic assignment of the spiked-in virus families in the viral mock community were correctly identified at the family and genus level (see Additional file 2; Additional file 1: Figure S2d), lending further support for the accurate detection of viral families by MG-RAST. Although at the genus level, several other marine bacteria were also identified in addition to the Synechococcus DC2 strain used to culture Myophage M2 and M3 suggesting possible bacterial contamination during the isolation of phage from seawater [67]. The presence of Phycodnaviridae, a large dsDNA virus that infects eukaryotic algal cells [68], in the wastewater samples suggests that phytoplankton and other algal cells may also be present during wastewater treatment. Previous metagenomic studies have reported Phycodnaviridae as a lesser abundant virus in wastewater $[64,69]$.

Further investigation of the phage metagenomes by the alpha-diversity indices in Fig. 3 show that these metagenomes were highly diverse and evenly dispersed. Linear regression analysis of the changes in diversity and evenness across treatments was not significant suggesting that treatment did not affect phage diversity (Fig. 3). Each phage metagenome was also compared by PCoA (Fig. 1b) revealing clustering of RS, RAS, and EFF samples together indicating similarity across treatments. The T3 and T4 SC samples did not cluster together, deviating across the $\mathrm{y}$ - and $\mathrm{x}$-axis respectively. When examining the rarefaction curves, phage diversity was not fully captured as most phage metagenomes did not reach an asymptotic plateau (Additional file 1: Figure S1). This suggests that the effect of treatment on lower abundant phage species may not have been adequately detected. This is however expected and consistent with the fact that the majority of phages remain as unidentified dark matter requiring deeper sequencing and improved bioinformatic techniques to capture this diversity $[15,70]$. Furthermore, PCoA including all metagenomic sequencing samples demonstrated two completely separated clusters for bacteria and phage (Additional file 1: Figure S3). Alongside the increased percentage of viral reads in the phage samples (4.69$20.01 \%$ ) compared to bacterial samples (0.03-0.23\%) 
based on MG-RAST annotation (Additional file 1: Table S1), these results indicate that the study methods were effective in reducing bacterial abundance and differentiating the bacterial and phage fractions.

\section{Comparison of GCN across treatments and time}

Integron-integrase MGE biomarkers intI1, intI2, and intI3 were quantified as a proxy for measuring variation in ARG dissemination between treatments due to their presence on transposons often associated with conjugative plasmids containing ARGs [8, 18, 71]. Normalized GCN per milliliter and per nanogram of DNA
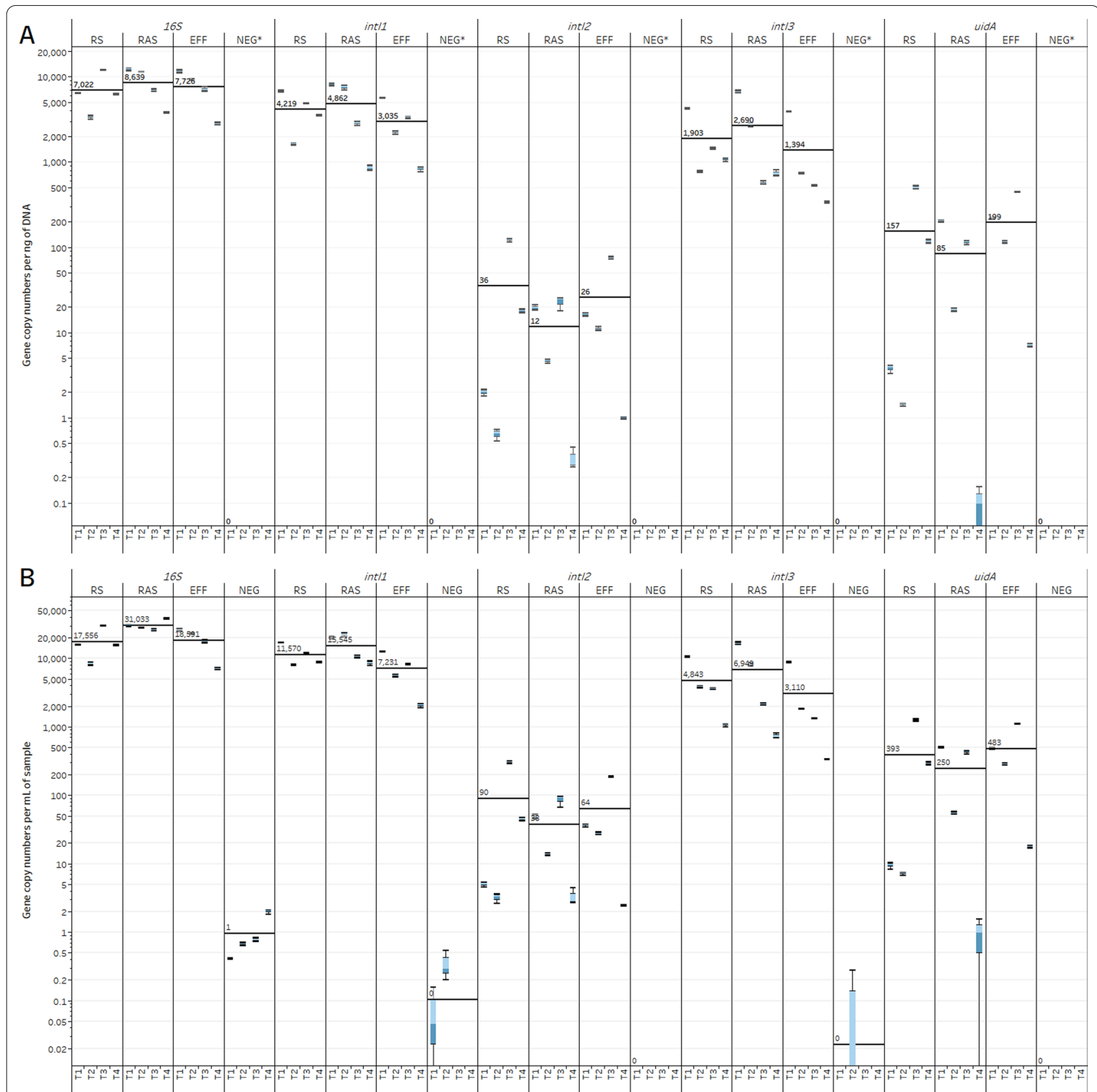

Fig. 4 Gene copy numbers of selected genes per milliliter of sample (A) and per nanogram of DNA (B) for the various wastewater treatment processes over a four-month period. The black lines represent the mean for each treatment over four months. Effluent (EFF), returned activated sludge (RAS), raw sewage/influent (RS), negative control (NEG), October (T1), November (T2), December (T3), February (T4). *DNA concentration was below the detectable limit therefore gene copy number per nanogram of DNA could not be quantified 
show that intI1 and intI3 were the most prevalent integron-integrase genes within all treatments over the fourmonth period (Fig. 4). However, intI2 remained at low abundance throughout the treatment with a mean normalized GCN of $6.40 \times 10^{1}$ gene copies per milliliter of sample and $2.50 \times 10^{1}$ gene copies per nanogram of DNA (Fig. 4). Class I integrons carrying intI1 have previously been shown to be the most abundant class of integrons in WWTPs and often contain clinically important ARGs [9, 18 , 72]. Concordantly, intI1 was the most abundant integrase detected in all treatments with a mean of $1.14 \times 10^{4}$ gene copies per $\mathrm{mL}$ and $4.00 \times 10^{3}$ gene copies per $\mathrm{ng}$ DNA (Fig. 4). The presence of intI1 is associated with specific resistance gene families such as streptomycin resistance genes $(a d d A)$, sulfonamide resistance genes (sul1 and sul2), as well as captured beta-lactam resistance genes $[18,72-74]$. The findings of low GCN abundance of intI2 across the different treatments (Fig. 4) is surprising given its association with common human gut bacteria within the Enterobacteriaceae family [28, 74]. Class III integron-integrase intI3 also had a higher abundance in the NESTP with a mean of $4.97 \times 10^{3}$ gene copies per $\mathrm{mL}$ and $1.99 \times 10^{3}$ gene copies per ng DNA. The class III integron-integrases have previously been associated with beta-lactamases blaGES and blaIMP which were found in several samples in the current study (see Additional file 3), but whether these genes are present within the integron is uncertain $[9,18,74]$.

Overall, NESTP wastewater treatment across all measured time points did not significantly change any of the MGE biomarkers targeted in this study (p-value $>0.05$ ). This suggests that stable ARG dissemination within the NESTP may be possible throughout treatment and in the downstream aquatic environment as MGEs were present in UV-treated EFF. All pairwise comparisons between treatments and the negative control for each integron-integrase gene were significant ( $p$-value $<0.05$ ). Pairwise comparison of intI3 between T1 and T4 across treatments was significantly different (p-value of 0.0074) indicating a decrease in intI3 GCN towards the colder winter months in Manitoba (Fig. 4) although whether this constitutes seasonal variation or not requires further sampling. No other significant differences were detected between months across treatments.

The 16S rRNA GCN Tukey-Kramer test did not reveal any significant differences between 16S rRNA GCNs across treatments or between treatments across the four time points ( $p$-value $>0.05$ ). Only pairwise comparisons between treatments and the negative control for each month was significant (p-value $<0.0001$ ). These results indicate that there was little variation in bacterial abundance across both treatments and monthly time points. Bacterial abundance measured in GCN per ng of DNA remained consistent through treatment but decreased nearly twofold from RAS to EFF in GCN per $\mathrm{ml}$ of sample although this was not significant (Fig. 4). This suggests that UV disinfection was able to reduce bacterial abundance although not as effectively as other studies that demonstrate 16S rRNA log-fold reductions after secondary clarification and UV disinfection [75] as well as chlorine disinfection [20]. The cold temperatures during the sampling events (ranging from $-18.6{ }^{\circ} \mathrm{C}$ to $2.8^{\circ} \mathrm{C}$ ) and grab temperatures around $13.6^{\circ} \mathrm{C}$ (Table 1) may have reduced the efficacy of UV disinfection although also reducing potential reactivation of UV irradiated cells [76, 77]. Other factors that may have contributed to reducing the effectiveness of UV disinfection include high BOD, COD, TSS, low hydraulic retention time, and precipitation (Table 1) [78]. However, when comparing by bacterial richness and evenness there is an observed increase from RS to RAS with the addition of activated sludge which decreases after UV treatment, although this is not significant ( $p>0.05$; Fig. 3). There was also a non-significant increase in Chao1 richness in EFF (Fig. 3c) possibly due to the bias of the Chaol diversity index towards low abundance species [21] which likely occurred after UV disinfection. A similar pattern was observed in WWTPs from comparably cold climates [79].

No significant differences were detected between treatments across the four time points for uidA ( $\mathrm{p}$-value $>0.05)$. Although not significant, there was a decrease in average GCN from RS to RAS (Additional file 1: Figure S4). The RS, often containing representative microbial communities of the human gut microbiota [80], had a relative abundance of uidA to $16 \mathrm{~S}$ rRNA gene of $1.55 \%$, which decreased to $0.88 \%$ with the addition of activated sludge for biological treatment of the influent (Additional file 1: Figure S4). This suggests a possible dilution of $E$. coli and other coliform bacteria in RAS with the addition of a diverse community of bacteria in the sludge. The subsequent increase in its relative abundance from RAS (0.88\%) to EFF (2.44\%) however, cannot be attributed to the removal of specific bacteria. Culturedependent $E$. coli and fecal coliform counts show an average of only 3.2 colonies present per milliliter of EFF (Table 1). The uidA results suggest that current UV disinfection practices may be insufficient to reduce $E$. coli and coliforms in EFF. However, culture-dependent counts for $E$. coli are within acceptable limits for the NESTP with the exception of T4 (Table 1). This discrepancy may be explained by the indiscriminate detection of DNA from both viable and nonviable cells by qPCR [81] especially since cold temperatures reduce the potential for UV-irradiated cell reactivation [77]. The difference in uidA ratios could also be due to the retention time between influent and effluent as well as UV disinfection efficacy. 


\section{Characterization of the North End Sewage Treatment Plant resistome}

The presence and identity of ARGs in each treatment and fraction was determined using CARD [36]. ARGs identified with below $50 \%$ identity match to the reference were filtered out. Additionally, the datasets generated for each sample were manually curated to remove inferred resistance through variation of targeted structural genes. These variants are structurally resistant to antibiotics including elfamycin, rifamycin, ethambutol, fluoroquinolones, diaminopyrimidine, and other drugs [82]. This also included removing resistance-nodulation-division efflux pumps because their primary function may not be the efflux of antibiotics [83], and this cannot be elucidated in the present study methods. The remaining resistance genes were grouped into major antibiotic classes: aminoglycosides, beta-lactams, chloramphenicols, fluoroquinolones, glycopeptide antibiotics, macrolides, nucleoside antibiotics, peptide antibiotics, sulfonamides, quaternary ammonium compounds (QACs), tetracyclines, multiple (resistance against 3 or more different antibiotic classes), and other antibiotics (residual efflux resistance genes against antibiotics not belonging to the major classes reported). The curated CARD datasets are found in Additional file 3.

\section{Resistome of the bacterial fraction}

Antibiotic resistance genes targeting most classes of antibiotics were detected across wastewater samples. When separated into fractions, the bacterial fractions contained a more diverse set of ARGs across treatments compared to bacteriophages (Fig. 5). Results over the sampling period showed a consistent relative abundance across the different ARG classes in the bacterial fraction (Fig. 5a). The most abundant class of antibiotic resistance in each process was resistance against tetracyclines $(17.86 \% \pm 0.03 \%)$ followed by peptide antibiotics $(14.24 \% \pm 0.03 \%)$, macrolides $(10.63 \% \pm 0.02 \%), \beta$-lactams $(8.00 \% \pm 0.03 \%)$, as well as the other $(16.28 \% \pm 0.02 \%)$ and multiple $(13.63 \% \pm 0.03 \%)$ categories (Fig. 5a). Differences in the abundance of ARGs across treatment processes was observed in Fig. $5 \mathrm{~b}$ where the abundance of ARGs increased from RS to RAS and subsequently decreased in the EFF, except for the T3 sampling event. This trend may well be explained by the introduction of microorganisms within the activated sludge that could carry additional ARGs, contributing to the composition of the resistome. After UV treatment, the number of ARGs decreases with the relative distribution remaining even across ARG classes (Fig. 5a and b). The NESTP reduced the overall abundance of ARGs in the EFF in T2, T3, and T4 (Fig. 5b).
The high relative abundance of tetracycline, multiple, and other ARGs was also observed when transformed to normalized abundance although this appears to decrease after UV treatment (Fig. 6a). SC shows an enrichment of ARGs against tetracycline, macrolides, peptide antibiotics, multiple and other efflux mechanisms compared to other T3 and T4 treatments (Fig. 6a). Although this enrichment is not observed to the same degree from RS to EFF, the presence of ARGs in EFF and SC raises concerns about their release and usage for irrigating and fertilizing agricultural soils as this represents a potential source for the reintroduction of antibiotic resistance accumulating pathogens into communities and hospitals [61].

\section{Bacterial ARGs of concern}

Examination of the curated CARD datasets (see Additional file 3) revealed the presence of many clinically relevant ARGs in the RS, RAS, EFF, and SC. Resistance against vancomycin, a glycopeptide antibiotic used to treat severe gram-positive infections [84], was detected throughout wastewater treatment, with the exception of T2 EFF. Components of the vancomycin resistance operon such as variants of the vanRS two component regulatory system were detected alongside the variable ligases $v a n A, v a n B, v a n C$, vanD, $v a n G$, and $v a n N$ [85]. However, the exact variants present cannot be elucidated at the sequencing depths used. Regardless, the presence of these operons in the WWTP is concerning due to their potential to be located on MGEs capable of transferring to pathogenic gram-positive enterococci or other opportunistic pathogens such as methicillin resistant Staphylococcus aureus (MRSA), however, transfer of $v a n A$, if present, to MRSA is thought to be rare $[85,86]$. Several vancomycin ligases were detected in the EFF and SC. Macrolide resistance was found in all samples and specific mechanisms of macrolide resistance of interest found in wastewater treatment were efflux pumps and ribosomal methyltransferases. Between the EFF and SC samples, MGE-associated efflux and ribosomal methyltransferases resistance genes were detected including mel, mef, $\operatorname{erm}(B)$, and $\operatorname{erm}(G)$ [87]. These resistance genes have been found in several of the ESKAPE group pathogens [87] as well as on transposons associated with Streptococcus pneumoniae [88]. The spread of macrolide resistance is important to mitigate as macrolides are one of the most prescribed types of antibiotics in the United States used to treat upper respiratory infections [88]. The presence of other clinically relevant resistance genes such as $b l a_{C T X-M}, b l a_{O X A}$, and $b l a_{I M P}, m c r$ mobile colistin resistance gene variants, and mobile tetracycline resistance genes $(\operatorname{tet}(A), \operatorname{tet}(B)$ and $\operatorname{tet}(M))$ were detected in 

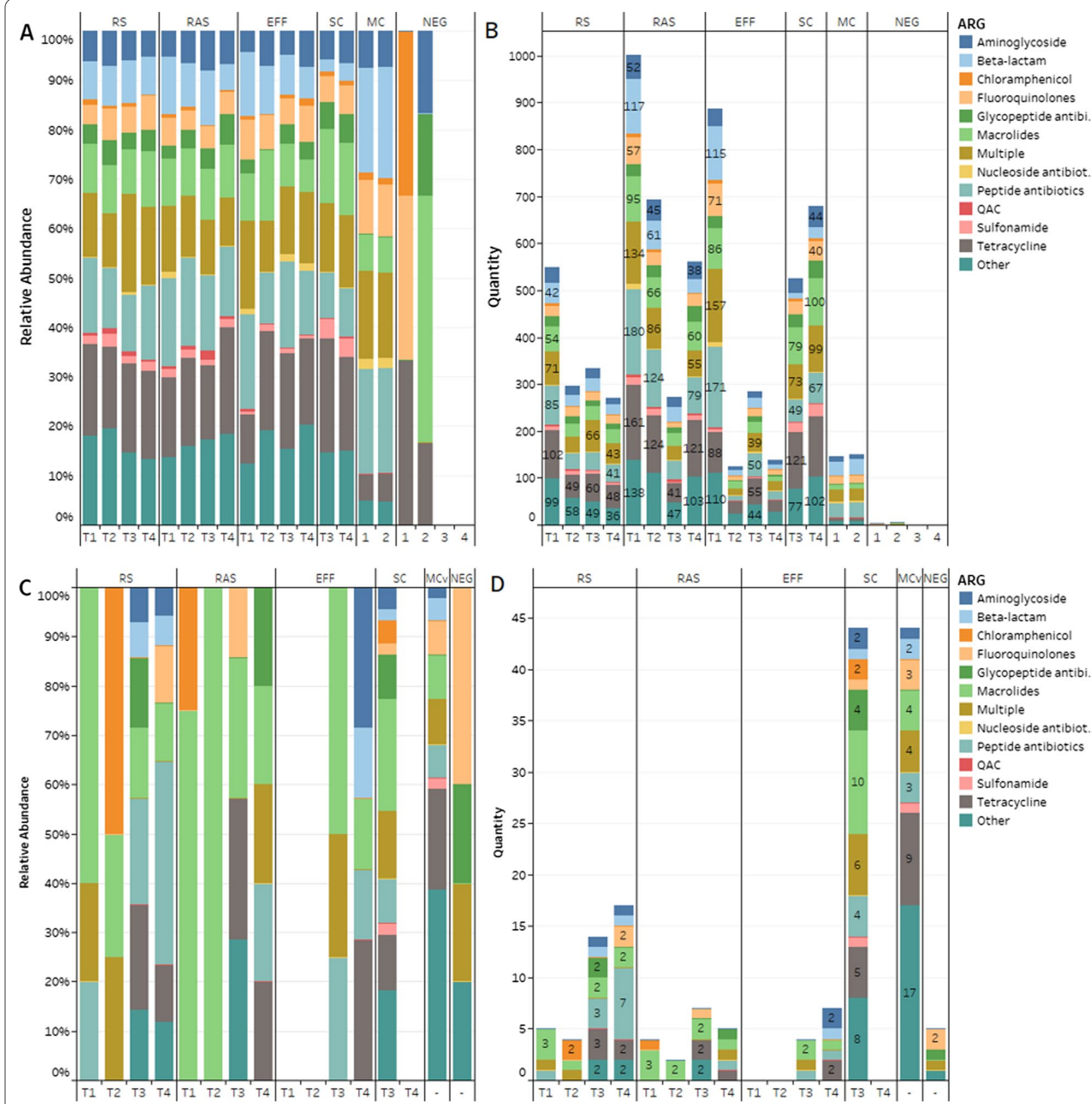

Fig. 5 Composition of antibiotic resistance genes in various treatment processes over 4 months. A Relative abundance and $\mathbf{B}$ absolute abundance of antibiotic resistance genes identified by CARD in the bacterial samples. C Relative abundance and $\mathbf{D}$ absolute abundance of antibiotic resistance genes identified by CARD in the phage samples. Effluent (EFF), returned activated sludge (RAS), raw sewage/influent (RS), dewatered sludge (SC), negative control (NEG), October (T1), November (T2), December (T3), February (T4)

many of the EFF and SC samples (see Additional file 3). Additionally, the tet(X6) mobile tigecycline resistance gene was putatively detected in the T1 EFF, T3 SC, and T4 SC. Colistin and tigecycline are last resort antibiotics that were only recently discovered to have mobile resistance genes $[89,90]$. The detection of these resistance genes in the NESTP is concerning given their potential for dissemination to clinically relevant pathogens such as those in the ESKAPE group. Overall, the presence of these clinically important ARGs within wastewater at the NESTP raises concerns about the possibility of ARG transfer and increased antibiotic 

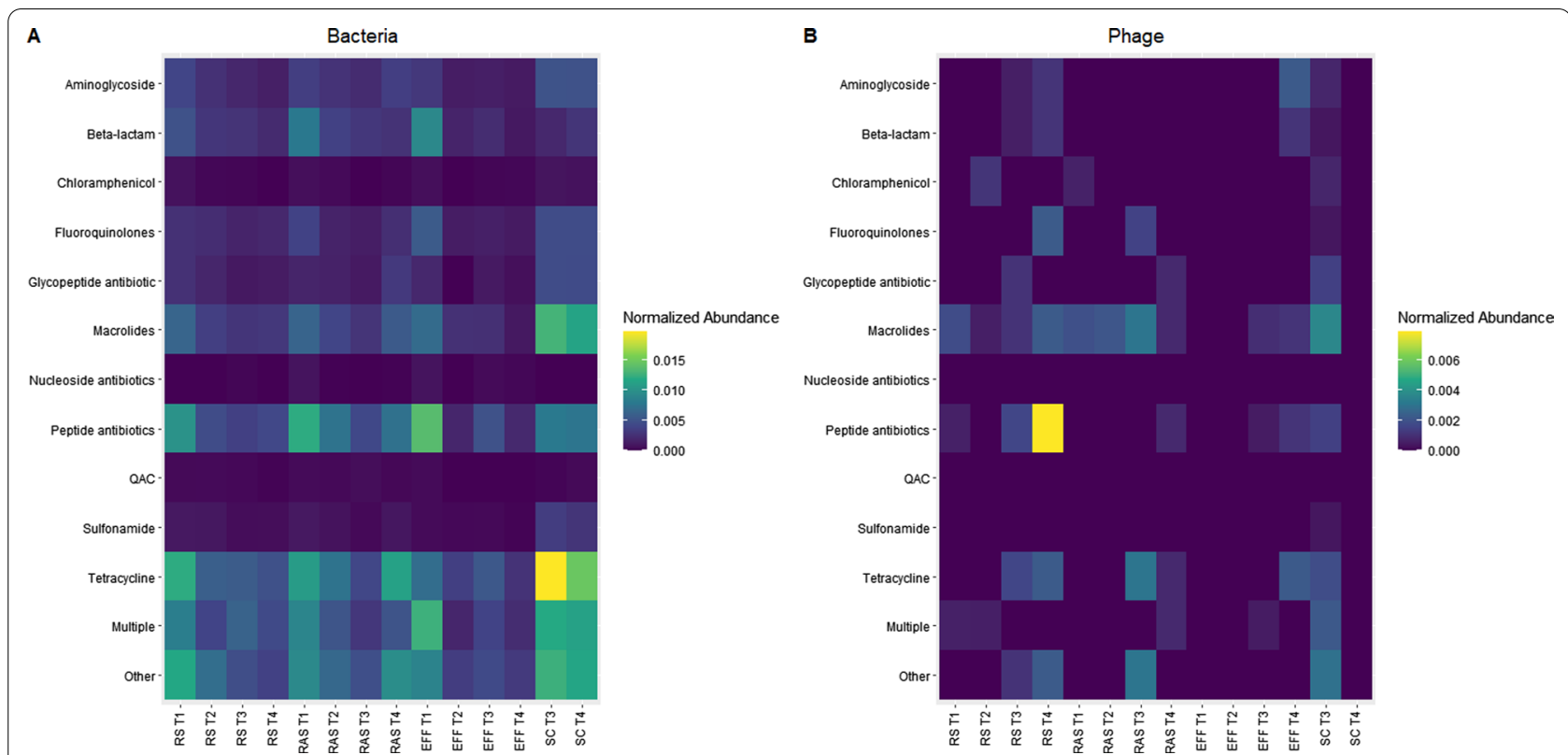

Fig. 6 Heatmap of antibiotic resistance classes. A Bacterial fraction. B Phage fraction. Effluent (EFF), returned activated sludge (RAS), raw sewage/ influent (RS), dewatered sludge (SC), October (T1), November (T2), December (T3), February (T4)

resistance in the environment as a result of these microbial pollutants [16].

\section{Resistome of the phage fraction}

The phage metagenomes were also run through CARD RGI following the same parameters and filtering criteria as the bacterial fraction. Overall, there was a tenfold decrease in the abundance of ARGs in the phage samples compared to bacteria. This was higher than Wang et al. who reported an overall 18-fold decrease in ARG abundance between fractions [12], although this was in a swine feedlot where the ratio of phage to bacteria may be lower compared to human or other anthropogenic environments [91]. The most common ARGs found in the phage samples were resistance against macrolides $(30.12 \% \pm 0.30 \%)$, peptide antibiotics $(10.78 \% \pm 0.13 \%)$, tetracyclines $(8.69 \% \pm 0.11 \%)$, and multiple $(7.40 \% \pm 0.11 \%)$ (Fig. $5 \mathrm{c}$ ). The ARG classes observed for phage are concordant with those found in the bacterial resistome although at differing relative abundances. Overall, the abundance of phage ARGs appears to decrease with each subsequent treatment (Fig. 5d). Discordance in the SC phage ARGs was observed between $\mathrm{T} 3$ and T4 with roughly twice the number of ARGs in T3 than any other sample while no ARGs were detected in T4 (Fig. 5d). This suggests that the T3 SC sample may have been contaminated although further monitoring is required to confirm this observation. Macrolides were the most abundant ARGs in the phageome and were consistently observed in RS and RAS before declining in EFF (Fig. 6b). Peptide antibiotics were sparsely distributed across samples with the exception of the T4 RS, which contained several ARGs previously only observed in the bacterial fraction (Fig. 6b). Only two putative $\beta$-lactam ARGs were observed in the T3 and T4 RS (Fig. 5d). This result was surprising since multiple studies have reported $\beta$-lactam and tetracycline ARGs as the most abundant classes in phage [11, 12, 92]. Nayfach et al. report lincosamides (categorized as macrolides here) as the most abundant ARGs followed by $\beta$-lactams and tetracyclines when using CARD RGI [15]. Apart from $\beta$-lactams, the ARG profile was similar to that presented here.

\section{Detection of clinically relevant ARGs in phage metagenomes}

Phage acquisition of ARGs is generally thought to occur through generalized transduction or non-specific packaging of bacterial DNA instead of phage DNA in the capsid [61]. Therefore, bacterial originating ARGs are more likely than bona fide phage ARGs. Investigation of the complement of ARGs detected in phage metagenomes revealed a core set of streptogramin resistance genes known as virginiamycin $O$-acetyltransferase (vat) enzymes (see Additional file 3). At least one of the following vat genes were detected in nearly all phage metagenomes: vatB, vatH, vatI, and vatF. Moon et al. [65] also reported the presence of vat genes (vatA and vatB) in the phageome of a freshwater river. However, these putative 
phage associated ARGs were not tested for resistance. The APH $\left(3^{\prime}\right)$-ia aminoglycoside resistance gene was identified in the T4 EFF with a $94-100 \%$ sequence identity match. $\mathrm{APH}\left(3^{\prime}\right)$-ia is a $3^{\prime}$-phosphotransferase that inhibits aminoglycoside antibiotics through the antibiotic target inactivation mechanism [93]. This high confidence match suggests that this ARG may be a true positive although whether this originated from phage or contaminating bacterial DNA is uncertain and warrants further investigation.

\section{Considerations and limitations of phage-associated ARG detection}

The viral negative control was composed of the flowthrough of each negative control generated per sample processing event. A total of roughly $800 \mathrm{~mL}(200 \mathrm{~mL}$ flow-through per event) was collected and concentrated for viral-like particles. This control contained a few ARGs belonging to classes that were less frequently represented in the treatment samples. These consisted of ARGs conferring resistance against fluoroquinolones, glycopeptide antibiotics, multiple, and other residual efflux resistance genes. Only the T3 RAS and SC phage resistome overlapped with the negative control containing the patB and novA genes. patB is an ARG typically associated with Streptococcus, which may have been a contaminant during DNA extraction as it has been identified in the kitome [43]. Metagenomic sequencing of the phage samples yielded a similar number of reads to the bacterial samples (Additional file 1: Table S1) with the percentage of phage reads ranging from $4.69 \%$ to $20.01 \%$ of the total reads based on MG-RAST annotation. This percentage of phage reads in the metagenomes was similar to Moon et al. [65] and higher than that reported by Subirats et al. [11] suggesting that the repeated $0.2 \mu \mathrm{m}$ filtration of the flow-through before concentrating viral particles was successful in reducing bacterial contamination. The low percentage of phage reads may be partially explained by the misclassification of prophages as originating from bacteria [70]. However, this remains a limitation for the analysis of the phage resistome [11]. A higher input volume to concentrate more virus-like particles may overcome this limitation by increasing the number of phage reads as well as the abundance of ARGs detected. This could also help reduce the risk of false positive ARG calls from potential contaminants. The detection of putative phage ARGs in the current study as well as previous studies [11, 12, 65] suggest that phages may represent an additional reservoir for the propagation of antibiotic resistance through transduction [94]. Future studies should consider increasing metagenomic sequencing depth and using longer reads (e.g., Nanopore technology) to better characterize individual phage.
These studies should also aim to isolate phages containing ARGs in order to characterize resistance, host range, as well as transduction rates to determine their potential to spread antibiotic resistance, especially to the ESKAPE group pathogens $[94,95]$.

\section{Co-occurrence of bacteria, phage, and ARGs}

We explored co-occurrences between ARGs and bacterial and phage families using network analysis and visualization. Relative abundances were used instead of absolute abundances to eliminate the potential bias that may arise from differences in the number of reads between samples and sequencing runs. Furthermore, only correlations with rho $>0.8$ and $\mathrm{p}$-value $<0.01$ were included for visualization purposes. Figure 7 illustrates the network generated using information from EFF samples. Corresponding graphs for RS (Additional file 1: Figure S5), RAS (Additional file 1: Figure S6), and SC (Additional file 1: Figure S7) can be found in Additional files.

Figure 7 comprises 45 nodes and 66 edges. The average degree is 2.933 , the average path length is 1.015 , and the network diameter is 2 . The phage families with the highest relative abundances (indicated by the biggest size of their nodes) were Siphoviridae and Podoviridae. This prevalence is consistent with previous literature [64, 96].

Some of the co-occurrences seen in Fig. 7 may be partially explained by host-phage relationships. For instance, Siphoviridae has been reported to infect Mycobacteriaceae [97] and Nocardiaceae (Rhodococcus) [98]. Other potential explanations for co-occurrences involve diet and habitat. For example, Phycodnaviridae is a common inhabitant of the human gut [99], which may explain its co-occurrence with several bacterial families, such as Bacteroidaceae, Enterobacteriaceae, and Pseudomonadaceae [91, 100]. Meanwhile, co-occurrences of bacterial ARGs with bacterial families may be partially due to the latter carrying the former. This hypothesis is similar to that posited by Li et al. [101], which suggests that certain microbial taxa carry specific ARGs. Furthermore, phages from shed gut bacteria readily transduce other environmental bacteria, disseminating ARGs in the process [62, 91, 94, 102, 103].

Of the network analyses, the graph for SC samples (Additional file 1: Figure S7) is notable. This network exhibits very strong co-occurrence patterns among all ARGs and phylogenetic groups, which may be explained by the fact that microorganisms and other solids are more densely packed in the SC [104]. These results may suggest that there is an increased exchange of ARGs in the SC compared to other processes [105]. More steps should be taken to further treat this SC since it is used to fertilize farmlands [106] and thus could spread ARGs and pathogens to agricultural products. 
Bacteria, family

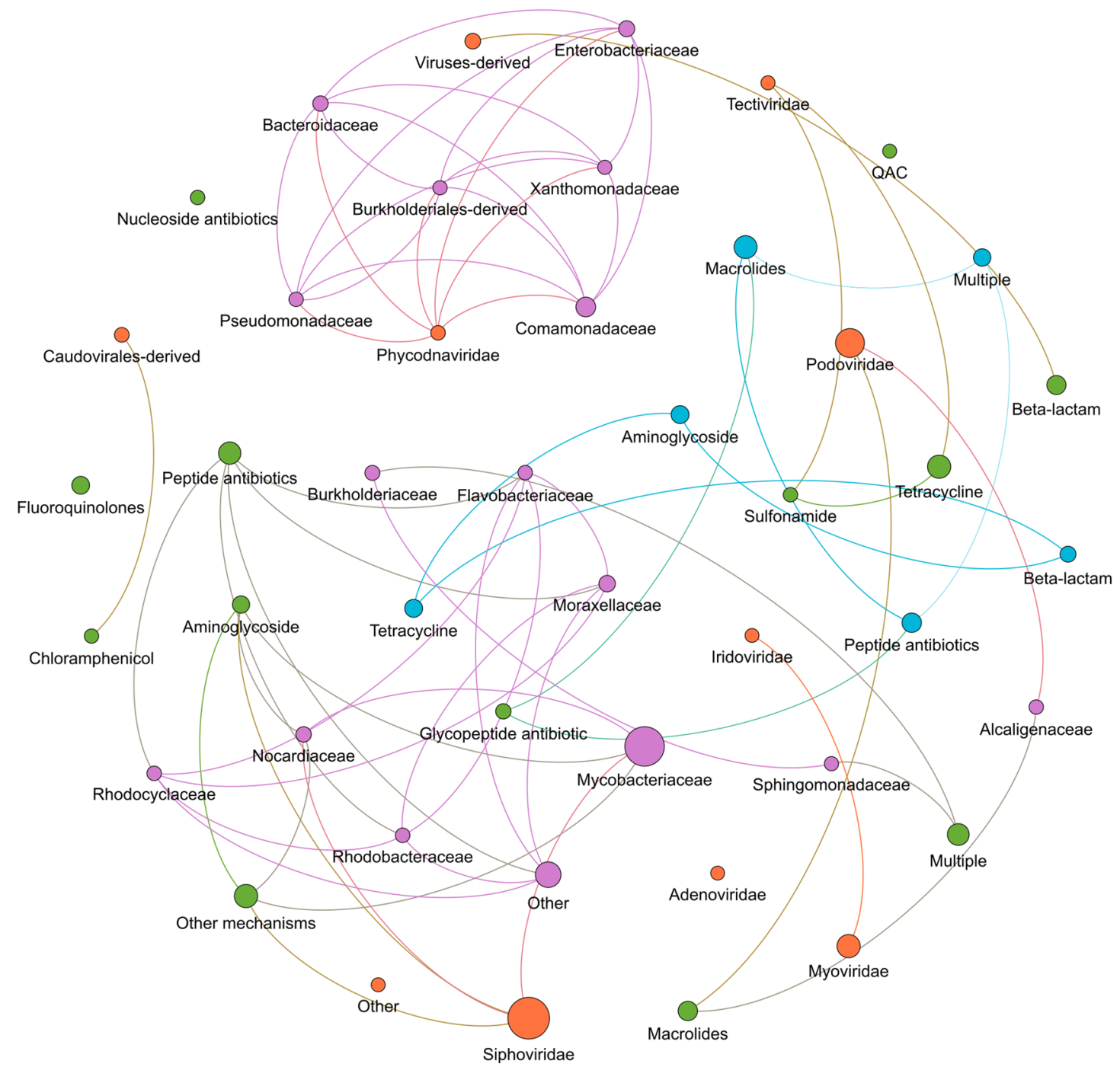

Fig. 7 Network analysis of co-occurrence patterns among ARGs and microbial taxa in EFF samples. Node sizes correspond to relative abundances. Antibiotic resistance gene (ARG), effluent (EFF)

In general, the presence of various ARGs and bacterial \& phage families in EFF samples indicates that they were not removed by the wastewater treatment process. Thus, discharging EFF into rivers incurs the risk of disseminating pathogens, antibiotic resistance genes, and possibly antibiotic-resistant pathogens. Therefore, future studies should monitor the presence of ARGs as well as bacterial and phage taxa downstream of wastewater treatment plants. Additionally, more studies on the co-occurrence of ARGs and human bacterial pathogens in environmental reservoirs, as well as subsequent analyses, should be conducted to establish and validate newfound potential relationships between ARGs and microorganisms of public health importance.

\section{Conclusion}

The bacterial composition at the class level for each wastewater treatment process closely resembled other studies with a core set of bacteria: Actinobacteria, Betaproteobacteria, and Gammaproteobacteria [40-42]. Further analysis at the genus level revealed that Mycobacteria, Polaromonas, and Acidovorax were found at higher 
relative abundances with the latter two genera possibly explained by the colder operating temperatures of the NESTP during the Fall and Winter months.

DNA phage in the NESTP consisted almost entirely of Siphoviridae, Podoviridae, and Myoviridae belonging to the Caudovirales order. These phages are known to infect several of the most abundant bacteria in the NESTP including Mycobacteria, Acinetobacter, and Pseudomonas $[63,66]$. Another interesting phage detected at $1 \%$ relative abundance was Phycodnaviridae, an algae-infecting phage and an inhabitant of the human gut. This phage was found to co-occur with several gut bacteria suggesting that its presence in wastewater is due to human waste rather than from the surrounding environment.

The NESTP resistome consisted of all classes of ARGs studied. The most abundant ARG classes in the bacterial and phage resistomes were resistance against tetracyclines, peptide antibiotics, and macrolides. In the bacterial fraction, several clinically relevant ARGs were detected in the EFF and SC including MGE-associated macrolide ARGs and mobile resistance genes $(\mathrm{mcr}$ and tet(X6)). The phage resistome also contained ARGs largely consisting of streptogramin resistance as well as the aminoglycoside resistance gene $\mathrm{APH}\left(3^{\prime}\right)$-ia identified with high sequence identity match. These results support recent reports of phages carrying ARGs and their potential role in disseminating resistance through transduction $[11,12,15,61]$.

Wastewater treatment effectively reduced the abundance of ARGs from the RS to the EFF in both bacterial and phage samples although certain clinically relevant ARGs remained in both the EFF and SC. This raises concerns about the potential risk of antibiotic resistance dissemination into downstream watersheds and agricultural lands that may use the anaerobically digested biosolids as fertilizer. This dissemination of ARGs downstream of the NESTP may serve as a potential route for reintroduction into communities and healthcare settings.

Further analysis of integron-integrase MGE biomarkers shows that intII and intI3 were the most abundant biomarkers. intI2 was also detected but with low GCN across treatments. Statistical analyses suggest that current wastewater treatment is insufficient at removing MGEs during the fall and winter months. The presence of these MGE biomarkers and clinically relevant ARGs in EFF amplifies the potential risk for the dissemination of antibiotic resistance in wastewater. This includes the transfer of resistance between environmental bacteria as well as pathogenic bacteria such as those in the ESKAPE group, which were detected throughout the NESTP. This is especially concerning given that the measured integron-integrase genes can contain gene cassettes conferring multidrug resistance [74]. Further analysis of integron-integrase GCN differences across more seasons will be required to determine the extent of integron-integrase variation within the NESTP.

This is the first study exploring the microbial composition and resistome of the NESTP, the largest WWTP in Manitoba, using shotgun metagenomics. The results of this study establish a baseline for future studies examining the effect of modifying operational parameters on microbial diversity as well as antibiotic resistance in the NESTP as it continues to be upgraded. This study also contributes to our understanding of the effects of colder climates on the resistome and community composition in a full-scale WWTP.

\section{Abbreviations}

ARG: Antibiotic resistance gene; BOD: Biological oxygen demand; CARD: Comprehensive Antibiotic Resistance Database; COD: Chemical oxygen demand; EFF: Effluent; ESKAPE: Enterococcus faecium, Staphylococcus aureus, Klebsiella pneumoniae, Acinetobacter baumannii, Pseudomonas aeruginosa, And Enterobacter spp; GCN: Gene copy number; MGE: Mobile genetic element; MG-RAST: Metagenomic Rapid Annotation using Subsystem Technology; NESTP: North End Sewage Treatment Plant (Winnipeg, MB, Canada); PCA: Principal component analysis; PCoA: Principal coordinate analysis; QAC: Quaternary ammonium compounds; RS: Raw sewage or influent; RAS: Returned activated sludge; SC: Dewatered sludge or sludge cake; T1: October 22, 2019 sampling event; T2: November 28, 2019 sampling event; T3: December 18, 2019 sampling event; T4: February 6, 2020 sampling event; TN: Total nitrogen; TP: Total phosphorus; TOC: Total organic carbon; TSS: Total suspended solids; WWTP: Wastewater treatment plant.

\section{Supplementary Information}

The online version contains supplementary material available at https://doi. org/10.1186/s40793-022-00398-1.

Additional file 1. Supplementary tables and figures

Additional file 2. NESTP metadata, MG-RAST taxonomical classification datasets, and real-time PCR datasets

Additional file 3 . Curated CARD datasets

\section{Acknowledgements}

We would like to thank the City of Winnipeg and Palwinder Singh (University of Manitoba) for his assistance collecting and delivering samples from the NESTP to the Uyaguari laboratory. We would also like to thank Dr. Ann Brassinga and her laboratory at the University of Manitoba for providing $L$. pneumophila and L. longbeachae for the bacterial mock community. Thanks to the British Columbia Centre for Disease Control as well as Dr. Curtis Suttle and his laboratory at the University of British Columbia for providing the viruses for the viral mock community. This research was conducted at the University of Manitoba. We would like to acknowledge that the University of Manitoba campuses are located on the original lands of the Anishinaabeg, Cree, OjiCree, Dakota, and Dene peoples, and on the homeland of the Métis Nation.

\section{Authors' contributions}

PJ and KY collected the samples. PJ and JG performed the experiments. AG, $\mathrm{TL}$, and $\mathrm{KY}$ conducted additional validation experiments. PJ, $\mathrm{TL}$, and MM performed data analysis and visualization. JG and TL contributed to writing the manuscript. PJ wrote the manuscript. MM revised the manuscript. QY provided analysis tools, interpretation, and revised the manuscript. MUD designed the experiments and provided guidance throughout the experiments, analysis 
tools, data analysis, interpretation, and writing of the manuscript. All authors read and approved the final manuscript.

\section{Funding}

This project was financially supported by the University of Manitoba (UoM) through the Research Start-up Funds grant No. 322388 (Dr. Uyaguari), The UoM Research Grants Program, Grant No. 322930 (Dr. Uyaguari), and The Faculty of Science, UoM, collaborative Grant No. 322788 (Drs. Uyaguari and Yuan). No funding body played a role in the design, analysis, interpretation, or writing of the manuscript.

\section{Availability of data and materials}

The datasets supporting the conclusions of this article are included within the article (and its additional files).

\section{Declarations}

\section{Ethics approva}

Not applicable.

\section{Competing interests}

The authors declare that they have no competing interests.

\section{Author details}

'Department of Microbiology, University of Manitoba, 45 Chancellors Circle, Buller Building, Winnipeg, MB R3T 2N2, Canada. ${ }^{2}$ Department of Medical Microbiology and Infectious Diseases, University of Manitoba, Winnipeg, MB, Canada. ${ }^{3}$ Clayton H. Riddell Faculty of Environment, Earth, and Resources, University of Manitoba, Winnipeg, MB, Canada. ${ }^{4}$ Department of Civil Engineering, University of Manitoba, Winnipeg, MB, Canada. ${ }^{5}$ Present Address: Institute of the Environment, University of Ottawa, Ottawa, ON, Canada.

\section{Received: 9 October 2021 Accepted: 5 January 2022}

\section{Published online: 15 January 2022}

\section{References}

1. Lewtas K, Osman H, Gunn G, Roy D. Manitoba Prairie Lakes: Mass balance budget for nutrient management at Pelican Lake, Manitoba. 2017:36.

2. Varela AR, Manaia CM. Human health implications of clinically relevant bacteria in wastewater habitats. Environ Sci Pollut Res. 2013;20:355069. https://doi.org/10.1007/s11356-013-1594-0.

3. Jendrzejewska N, Karwowska E. The influence of antibiotics on wastewater treatment processes and the development of antibiotic-resistant bacteria. Water Sci Technol. 2018;77:2320-6. https://doi.org/10.2166/ wst.2018.153.

4. Kulkarni P, Olson N, Raspanti G, Rosenberg Goldstein R, Gibbs S, Sapkota $A$, et al. Antibiotic concentrations decrease during wastewater treatment but persist at low levels in reclaimed water. Int J Environ Res Public Health. 2017;14:668. https://doi.org/10.3390/ijerph14060668.

5. Kolpin DW, Furlong ET, Meyer MT, Thurman EM, Zaugg SD, Barber LB, et al. Pharmaceuticals, hormones, and other organic wastewater contaminants in U.S. streams, 1999-2000: a national reconnaissance. Environ Sci Technol. 2002;36:1202-11. https://doi.org/10.1021/es011 055j.

6. Karthikeyan KG, Meyer MT. Occurrence of antibiotics in wastewater treatment facilities in Wisconsin, USA. Sci Total Environ. 2006:361:196207. https://doi.org/10.1016/j.scitotenv.2005.06.030.

7. Kortesmäki E, Östman JR, Meierjohann A, Brozinski J, Eklund P, Kronberg L. Occurrence of antibiotics in influent and effluent from 3 major wastewater-treatment plants in Finland. Environ Toxicol Chem. 2020:39:1774-89. https://doi.org/10.1002/etc.4805.

8. Rizzo L, Manaia C, Merlin C, Schwartz T, Dagot C, Ploy MC, et al. Urban wastewater treatment plants as hotspots for antibiotic resistant bacteria and genes spread into the environment: a review. Sci Total Environ. 2013:447:345-60. https://doi.org/10.1016/j.scitotenv.2013.01.032.

9. An X-L, Chen Q-L, Zhu D, Zhu Y-G, Gillings MR, Su J-Q. Impact of wastewater treatment on the prevalence of integrons and the genetic diversity of integron gene cassettes. Appl Environ Microbiol. 2018;84:115. https://doi.org/10.1128/AEM.02766-17.

10. Karkman A, Do TT, Walsh F, Virta MPJ. Antibiotic-resistance genes in waste water. Trends Microbiol. 2018;26:220-8. https://doi.org/10.1016/j. tim.2017.09.005.

11. Subirats J, Sànchez-Melsió A, Borrego CM, Balcázar JL, Simonet P. Metagenomic analysis reveals that bacteriophages are reservoirs of antibiotic resistance genes. Int J Antimicrob Agents. 2016;48:163-7. https://doi.org/10.1016/j.ijantimicag.2016.04.028.

12. Wang M, Xiong W, Liu P, Xie X, Zeng J, Sun Y, et al. Metagenomic insights into the contribution of phages to antibiotic resistance in water samples related to swine feedlot wastewater treatment. Front Microbiol. 2018;9:2474. https://doi.org/10.3389/fmicb.2018.02474.

13. Hendrix RW, Smith MCM, Burns RN, Ford ME, Hatfull GF. Evolutionary relationships among diverse bacteriophages and prophages: All the world's a phage. Proc Natl Acad Sci. 1999;96:2192-7. https://doi.org/10. 1073/pnas.96.5.2192.

14. Mushegian AR. Are there 1031 virus particles on earth, or more, or fewer? J Bacteriol. 2020. https://doi.org/10.1128/JB.00052-20.

15. Nayfach S, Páez-Espino D, Call L, Low SJ, Sberro H, Ivanova NN, et al. Metagenomic compendium of 189,680 DNA viruses from the human gut microbiome. Nat Microbiol. 2021;6:960-70. https://doi.org/10.1038/ s41564-021-00928-6.

16. Pruden A. Balancing water sustainability and public health goals in the face of growing concerns about antibiotic resistance. Environ Sci Technol. 2014;48:5-14. https://doi.org/10.1021/es403883p.

17. Frieden T. Antibiotic resistance threats in the United States. Centers Dis Control Prev. 2013:114.

18. Sultan I, Rahman S, Jan AT, Siddiqui MT, Mondal AH, Haq QMR. Antibiotics, resistome and resistance mechanisms: a bacterial perspective. Front Microbiol. 2018;9:2066. https://doi.org/10.3389/fmicb.2018.02066.

19. Scholz MB, Lo C-C, Chain PSG. Next generation sequencing and bioinformatic bottlenecks: the current state of metagenomic data analysis. Curr Opin Biotechnol. 2012;23:9-15. https://doi.org/10.1016/j.copbio. 2011.11.013.

20. Majeed HJ, Riquelme MV, Davis BC, Gupta S, Angeles L, Aga DS, et al. Evaluation of metagenomic-enabled antibiotic resistance surveillance at a conventional wastewater treatment plant. Front Microbiol. 2021;12:657954. https://doi.org/10.3389/fmicb.2021.657954.

21. Kim B-R, Shin J, Guevarra RB, Lee JH, Kim DW, Seol K-H, et al. Deciphering diversity indices for a better understanding of microbial communities. J Microbiol Biotechnol. 2017;27:2089-93. https://doi.org/10.4014/ jmb.1709.09027.

22. Barraud O, Baclet MC, Denis F, Ploy MC. Quantitative multiplex real-time PCR for detecting class 1, 2 and 3 integrons. J Antimicrob Chemother. 2010;65:1642-5. https://doi.org/10.1093/jac/dkq167.

23. Frahm E, Obst U. Application of the fluorogenic probe technique (TaqMan PCR) to the detection of Enterococcus spp. and Escherichia coli in water samples. J Microbiol Methods. 2003;52:123-31. https://doi. org/10.1016/S0167-7012(02)00150-1.

24. Ye J, Coulouris G, Zaretskaya I, Cutcutache I, Rozen S, Madden TL. Primer-BLAST: a tool to design target-specific primers for polymerase chain reaction. BMC Bioinform. 2012;13:134. https://doi.org/10.1186/ 1471-2105-13-134.

25. Kearse M, Moir R, Wilson A, Stones-Havas S, Cheung M, Sturrock S, et al. Geneious Basic: an integrated and extendable desktop software platform for the organization and analysis of sequence data. Bioinformatics. 2012;28:1647-9. https://doi.org/10.1093/bioinformatics/bts199.

26. Ritalahti KM, Amos BK, Sung Y, Wu Q, Koenigsberg SS, Löffler FE. Quantitative PCR targeting 16S rRNA and reductive dehalogenase genes simultaneously monitors multiple dehalococcoides strains. Appl Environ Microbiol. 2006;72:2765-74. https://doi.org/10.1128/AEM.72.4. 2765-2774.2006.

27. Lee ZM-P, Bussema C, Schmidt TM. rrnDB: documenting the number of rRNA and tRNA genes in bacteria and archaea. Nucleic Acids Res. 2009;37:D489-93. https://doi.org/10.1093/nar/gkn689.

28. Uyaguari MI, Scott GI, Norman RS. Abundance of class 1-3 integrons in South Carolina estuarine ecosystems under high and low levels of anthropogenic influence. Mar Pollut Bull. 2013;76:77-84. https://doi. org/10.1016/j.marpolbul.2013.09.027. 
29. Uyaguari-Diaz MI, Chan M, Chaban BL, Croxen MA, Finke JF, Hill JE, et al. A comprehensive method for ampliconbased and metagenomic characterization of viruses, bacteria, and eukaryotes in freshwater samples. Microbiome. 2016;4:1-19. https://doi.org/10.1186/s40168-016-0166-1.

30. Meyer F, Paarmann D, D'Souza M, Olson R, Glass E, Kubal M, et al. The metagenomics RAST server-a public resource for the automatic phylogenetic and functional analysis of metagenomes. BMC Bioinform. 2008;9:386. https://doi.org/10.1186/1471-2105-9-386.

31. McMurdie PJ, Holmes S. phyloseq: an R package for reproducible interactive analysis and graphics of microbiome census data. PLOS ONE. 2013;8:e61217. https://doi.org/10.1371/journal.pone.0061217.

32. Oksanen J, Blanchet FG, Friendly M, Kindt R, Legendre P, Mcglinn D, et al. Vegan: community ecology package. 2020. https://cran.r-project. org/package = vegan

33. Tableau (version. 9.1). J Med Libr Assoc. 2016;104:182-3. https://doi.org/ 10.3163/1536-5050.104.2.022

34. Wickham H. ggplot2: elegant graphics for data analysis. New York: Springer-Verlag; 2016. https://ggplot2.tidyverse.org.

35. RStudio Team. RStudio: integrated development for R. Boston, MA. 2020. http://www.rstudio.com/.

36. Alcock BP, Raphenya AR, Lau TTY, Tsang KK, Bouchard M, Edalatmand A, et al. CARD 2020: antibiotic resistome surveillance with the comprehensive antibiotic resistance database. Nucleic Acids Res. 2019;48:D517-25. https://doi.org/10.1093/nar/gkz935.

37. R Core Team (2021). R: a language and environment for statistical computing. R foundation for statistical computing, Vienna, Austria. https:// www.R-project.org/. 2021

38. Bastian M, Heymann S, Jacomy M. Gephi: an open source software for exploring and manipulating networks. In: Proceedings of the international AAAI conference on web and social media. 2009. p. 361-2. https://ojs.aaai.org/index.php/ICWSM/article/view/13937.

39. Inkscape Project. Inkscape. 2020. https://inkscape.org

40. Muszyński A, Tabernacka A, Miłobędzka A. Long-term dynamics of the microbial community in a full-scale wastewater treatment plant. Int Biodeterior Biodegrad. 2015;100:44-51. https://doi.org/10.1016/j.ibiod. 2015.02.008.

41. Oluseyi Osunmakinde C, Selvarajan R, Mamba BB, Msagati TAM. Profiling bacterial diversity and potential pathogens in wastewater treatment plants using high-throughput sequencing analysis. Microorganisms. 2019;7:506. https://doi.org/10.3390/microorganisms7110506.

42. Lira F, Vaz-Moreira I, Tamames J, Manaia CM, Martínez JL. Metagenomic analysis of an urban resistome before and after wastewater treatment. Sci Rep. 2020;10:8174. https://doi.org/10.1038/s41598-020-65031-y.

43. Salter SJ, Cox MJ, Turek EM, Calus ST, Cookson WO, Moffatt MF, et al. Reagent and laboratory contamination can critically impact sequencebased microbiome analyses. BMC Biol. 2014;12:87. https://doi.org/10. 1186/s12915-014-0087-z.

44. Zhang B, Xu X, Zhu L. Structure and function of the microbial consortia of activated sludge in typical municipal wastewater treatment plants in winter. Sci Rep. 2017;7:17930. https://doi.org/10.1038/ s41598-017-17743-x.

45. Kim T-S, Jeong J-Y, Wells GF, Park H-D. General and rare bacterial taxa demonstrating different temporal dynamic patterns in an activated sludge bioreactor. Appl Microbiol Biotechnol. 2013;97:1755-65. https:// doi.org/10.1007/s00253-012-4002-7.

46. Ju F, Guo F, Ye L, Xia Y, Zhang T. Metagenomic analysis on seasonal microbial variations of activated sludge from a full-scale wastewater treatment plant over 4 years. Environ Microbiol Rep. 2014;6:80-9. https://doi.org/10.1111/1758-2229.12110.

47. Daims H, Nielsen JL, Nielsen PH, Schleifer K-H, Wagner M. In situ characterization of nitrospira -like nitrite-oxidizing bacteria active in wastewater treatment plants. Appl Environ Microbiol. 2001;67:5273-84. https://doi.org/10.1128/AEM.67.11.5273-5284.2001.

48. Gonzalez-Martinez A, Rodriguez-Sanchez A, Lotti T, Garcia-Ruiz M-J, Osorio F, Gonzalez-Lopez J, et al. Comparison of bacterial communities of conventional and A-stage activated sludge systems. Sci Rep. 2016;6:18786. https://doi.org/10.1038/srep18786

49. Zhang $\mathrm{H}, \mathrm{He} \mathrm{H}$, Chen S, Huang $\mathrm{T}$, Lu K, Zhang Z, et al. Abundance of antibiotic resistance genes and their association with bacterial communities in activated sludge of wastewater treatment plants: geographical distribution and network analysis. J Environ Sci. 2019;82:24-38. https:// doi.org/10.1016/j.jes.2019.02.023.

50. Merzouki M, Delgenès J-P, Bernet N, Moletta R, Benlemlih M. Polyphosphate-accumulating and denitrifying bacteria isolated from anaerobic-anoxic and anaerobic-aerobic sequencing batch reactors. Curr Microbiol. 1999;38:9-17. https://doi.org/10.1007/PL00006776.

51. Gil-Pulido B, Tarpey E, Finnegan W, Zhan X, Dobson ADW, O'Leary N. Dominance of the genus Polaromonas in the microbial ecology of an Intermittently Aerated Sequencing Batch Reactor (IASBR) treating dairy processing wastewater under varying aeration rates. J Dairy Res. 2018;85:388-90. https://doi.org/10.1017/S0022029918000572.

52. Gawor J, Grzesiak J, Sasin-Kurowska J, Borsuk P, Gromadka R, Górniak $\mathrm{D}$, et al. Evidence of adaptation, niche separation and microevolution within the genus Polaromonas on Arctic and Antarctic glacial surfaces. Extremophiles. 2016;20:403-13. https://doi.org/10.1007/ s00792-016-0831-0.

53. He S, Ding L, Xu K, Geng J, Ren H. Effect of low temperature on highly unsaturated fatty acid biosynthesis in activated sludge. Bioresour Technol. 2016;211:494-501. https://doi.org/10.1016/j.biortech.2016.03.069.

54. Amha YM, Anwar MZ, Kumaraswamy R, Henschel A, Ahmad F. Mycobacteria in municipal wastewater treatment and reuse: microbial diversity for screening the occurrence of clinically and environmentally relevant species in arid regions. Environ Sci Technol. 2017;51:3048-56. https:// doi.org/10.1021/acs.est.6b05580.

55. Bohrerova Z, Linden KG. Ultraviolet and chlorine disinfection of mycobacterium in wastewater: effect of aggregation. Water Environ Res. 2006;78:565-71. https://doi.org/10.2175/106143006X99795.

56. Edgar RC. Accuracy of microbial community diversity estimated by closed- and open-reference OTUs. PeerJ. 2017;5:e3889. https://doi.org/ 10.7717/peerj.3889.

57. Randle-Boggis RJ, Helgason T, Sapp M, Ashton PD. Evaluating techniques for metagenome annotation using simulated sequence data. FEMS Microbiol Ecol. 2016;92:fiw095. https://doi.org/10.1093/femsec/ fiw095.

58. Carlet J, Jarlier V, Harbarth S, Voss A, Goossens H, Pittet D. Ready for a world without antibiotics? The Pensières Antibiotic Resistance Call to Action. Antimicrob Resist Infect Control. 2012;1:11. https://doi.org/10. 1186/2047-2994-1-11

59. De Oliveira DMP, Forde BM, Kidd TJ, Harris PNA, Schembri MA, Beatson SA, et al. Antimicrobial resistance in ESKAPE pathogens. Clin Microbiol Rev. 2020;33:e00181-e219. https://doi.org/10.1128/CMR.00181-19.

60. Savin M, Bierbaum G, Hammerl JA, Heinemann C, Parcina M, Sib E, et al. ESKAPE bacteria and extended-spectrum- $\beta$-lactamaseproducing Escherichia coli isolated from wastewater and process water from German Poultry Slaughterhouses. Appl Environ Microbiol. 2020;86:e02748-e2819. https://doi.org/10.1128/AEM.02748-19.

61. Colavecchio A, Cadieux B, Lo A, Goodridge LD. Bacteriophages contribute to the spread of antibiotic resistance genes among foodborne pathogens of the enterobacteriaceae family - a review. Front Microbiol. 2017;8:1108. https://doi.org/10.3389/fmicb.2017.01108.

62. Strange JES, Leekitcharoenphon P, Møller FD, Aarestrup FM. Metagenomics analysis of bacteriophages and antimicrobial resistance from global urban sewage. Sci Rep. 2021;11:1600. https://doi.org/10.1038/ s41598-021-80990-6.

63. O'Brien E, Munir M, Marsh T, Heran M, Lesage G, Tarabara VV, et al. Diversity of DNA viruses in effluents of membrane bioreactors in Traverse City, MI (USA) and La Grande Motte (France). Water Res. 2017;111:33845. https://doi.org/10.1016/j.watres.2017.01.014.

64. Petrovich ML, Ben Maamar S, Hartmann EM, Murphy BT, Poretsky RS, Wells GF. Viral composition and context in metagenomes from biofilm and suspended growth municipal wastewater treatment plants. Microb Biotechnol. 2019;12:1324-36. https://doi.org/10.1111/1751-7915.13464.

65. Moon K, Jeon JH, Kang I, Park KS, Lee K, Cha C-J, et al. Freshwater viral metagenome reveals novel and functional phage-borne antibiotic resistance genes. Microbiome. 2020;8:75. https://doi.org/10.1186/ s40168-020-00863-4.

66. Cha K, Oh HK, Jang JY, Jo Y, Kim WK, Ha GU, et al. Characterization of two novel bacteriophages infecting multidrug-resistant (MDR) Acinetobacter baumannii and evaluation of their therapeutic efficacy in vivo. Front Microbiol. 2018;9:696. https://doi.org/10.3389/fmicb.2018.00696. 
67. Finke JF, Suttle CA. The environment and cyanophage diversity: insights from environmental sequencing of DNA polymerase. Front Microbiol. 2019;10:167. https://doi.org/10.3389/fmicb.2019.00167.

68. Wilson WH, Van Etten $\mathrm{J}$, Allen MJ. The Phycodnaviridae: the story of how tiny giants rule the world. In: Current topics in microbiology and immunology. 2009. p. 1-42. https://doi.org/10.1007/ 978-3-540-68618-7_1.

69. Tamaki H, Zhang R, Angly FE, Nakamura S, Hong P-Y, Yasunaga T, et al. Metagenomic analysis of DNA viruses in a wastewater treatment plant in tropical climate. Environ Microbiol. 2012;14:441-52. https:// doi.org/10.1111/j.1462-2920.2011.02630.x

70. Roux S, Krupovic M, Debroas D, Forterre P, Enault F. Assessment of viral community functional potential from viral metagenomes may be hampered by contamination with cellular sequences. Open Biol. 2013;3:130160. https://doi.org/10.1098/rsob.130160.

71. Cambray G, Guerout A-M, Mazel D. Integrons. Annu Rev Genet. 2010;44:141-66. https://doi.org/10.1146/annur ev-genet-102209-163504

72. Zieliński W, Korzeniewska E, Harnisz M, Drzymała J, Felis E, Bajkacz S. Wastewater treatment plants as a reservoir of integrase and antibiotic resistance genes - an epidemiological threat to workers and environment. Environ Int. 2021;156:106641. https://doi.org/10.1016/j. envint.2021.106641.

73. Zheng W, Huyan J, Tian Z, Zhang Y, Wen X. Clinical class 1 integronintegrase gene-a promising indicator to monitor the abundance and elimination of antibiotic resistance genes in an urban wastewater treatment plant. Environ Int. 2020;135:105372. https://doi.org/10. 1016/j.envint.2019.105372.

74. Deng Y, Bao X, Ji L, Chen L, Liu J, Miao J, et al. Resistance integrons: class 1, 2 and 3 integrons. Ann Clin Microbiol Antimicrob. 2015;14:45. https://doi.org/10.1186/s12941-015-0100-6.

75. McConnell MM, Truelstrup Hansen L, Jamieson RC, Neudorf KD, Yost CK, Tong A. Removal of antibiotic resistance genes in two tertiary level municipal wastewater treatment plants. Sci Total Environ. 2018;643:292-300. https://doi.org/10.1016/j.scitotenv.2018.06.212.

76. Abu-ghararah $\mathrm{ZH}$. Effect of temperature on the kinetics of wastewater disinfection using ultraviolet radiation. J Environ Sci Heal Part A Environ Sci Eng Toxicol. 1994;29:585-603. https://doi.org/10.1080/ 10934529409376056

77. Salcedo I, Andrade JA, Quiroga JM, Nebot E. Photoreactivation and dark repair in UV-treated microorganisms: Effect of temperature. Appl Environ Microbiol. 2007;73:1594-600.

78. Garcia A, Le T, Jankowski P, Yanaç K, Yuan Q, Uyaguari-díaz M. Quantitation of human enteric viruses as alternative indicators of fecal pollution to evaluate wastewater treatment processes. bioRxiv. 2021. https://doi.org/10.1101/2021.08.05.455335.

79. Tiwari A, Hokajärvi AM, Domingo JS, Elk M, Jayaprakash B, Ryu H, et al. Bacterial diversity and predicted enzymatic function in a multipurpose surface water system-from wastewater effluent discharges to drinking water production. Environ Microbiomes. 2021;16:1-17.

80. Pärnänen KMM, Narciso-da-Rocha C, Kneis D, Berendonk TU, Cacace D, Do TT, et al. Antibiotic resistance in European wastewater treatment plants mirrors the pattern of clinical antibiotic resistance prevalence. Sci Adv. 2019;5:eaau9124. https://doi.org/10.1126/sciadv. aau9124.

81. Cangelosi GA, Meschke JS. Dead or alive: molecular assessment of microbial viability. Appl Environ Microbiol. 2014;80:5884-91.

82. Uyaguari-Díaz MI, Croxen MA, Luo Z, Cronin Kl, Chan M, Baticados WN, et al. Human activity determines the presence of integronassociated and antibiotic resistance genes in Southwestern British Columbia. Front Microbiol. 2018;9:852. https://doi.org/10.3389/fmicb. 2018.00852.

83. Fernando D, Kumar A. Resistance-nodulation-division multidrug efflux pumps in gram-negative bacteria: role in virulence. Antibiotics. 2013;2:163-81. https://doi.org/10.3390/antibiotics2010163.

84. Hashimoto Y, Kurushima J, Nomura T, Tanimoto K, Tamai K, Yanagisawa $\mathrm{H}$, et al. Dissemination and genetic analysis of the stealthy van $B$ gene clusters of Enterococcus faecium clinical isolates in Japan. BMC Microbiol. 2018;18:213. https://doi.org/10.1186/s12866-018-1342-1.

85. Faron ML, Ledeboer NA, Buchan BW. Resistance mechanisms, epidemiology, and approaches to screening for vancomycin-resistant enterococcus in the health care setting. J Clin Microbiol. 2016;54:2436-47. https://doi.org/10.1128/JCM.00211-16.

86. Oravcova V, Mihalcin M, Zakova J, Pospisilova L, Masarikova M, Literak I. Vancomycin-resistant enterococci with vanA gene in treated municipal wastewater and their association with human hospital strains. Sci Total Environ. 2017;609:633-43. https://doi.org/10.1016/j. scitotenv.2017.07.121.

87. van Hoek AHAM, Mevius D, Guerra B, Mullany P, Roberts AP, Aarts HJM. Acquired antibiotic resistance genes: an overview. Front Microbiol. 2011;2:203. https://doi.org/10.3389/fmicb.2011.00203.

88. Schroeder MR, Lohsen S, Chancey ST, Stephens DS. High-level macrolide resistance due to the mega element [mef(E)/mel] in Streptococcus pneumoniae. Front Microbiol. 2019;10:868. https://doi.org/ 10.3389/fmicb.2019.00868.

89. Liu Y-Y, Wang Y, Walsh TR, Yi L-X, Zhang R, Spencer J, et al. Emergence of plasmid-mediated colistin resistance mechanism MCR-1 in animals and human beings in China: a microbiological and molecular biological study. Lancet Infect Dis. 2016;16:161-8. https://doi.org/10.1016/ S1473-3099(15)00424-7.

90. He T, Wang R, Liu D, Walsh TR, Zhang R, LV Y, et al. Emergence of plasmid-mediated high-level tigecycline resistance genes in animals and humans. Nat Microbiol. 2019;4:1450-6. https://doi.org/10.1038/ s41564-019-0445-2.

91. Muniesa M, Imamovic L, Jofre J. Bacteriophages and genetic mobilization in sewage and faecally polluted environments. Microb Biotechnol. 2011;4:725-34. https://doi.org/10.1111/j.1751-7915.2011 00264.x.

92. Balcazar JL. Bacteriophages as vehicles for antibiotic resistance genes in the environment. PLoS Pathog. 2014;10:e1004219. https://doi.org/ 10.1371/journal.ppat.1004219.

93. Siregar JJ, Miroshnikov K, Mobashery S. Purification, characterization, and investigation of the mechanism of aminoglycoside $3^{\prime}$-phosphotransferase type la. Biochemistry. 1995;34:12681-8. https://doi.org/ 10.1021/bi00039a026.

94. Balcázar JL. Implications of bacteriophages on the acquisition and spread of antibiotic resistance in the environment. Int Microbiol. 2020;23:475-9. https://doi.org/10.1007/s10123-020-00121-5.

95. Rodwell E V., Wenner N, Pulford C V., Cai Y, Bowers-Barnard A, Beckett A, et al. Isolation and characterisation of bacteriophages with activity against invasive non-typhoidal salmonella causing bloodstream infection in malawi. Viruses. 2021;13.

96. Alič Š, Naglič T, Tušek-Žnidarič M, Ravnikar M, Rački N, Peterka M, et al, Newly isolated bacteriophages from the podoviridae, siphoviridae, and myoviridae families have variable effects on putative novel Dickeya spp. Front Microbiol. 2017;8:1870. https://doi.org/10.3389/fmicb. 2017.01870.

97. Hatfull GF, Cresawn SG, Hendrix RW. Comparative genomics of the mycobacteriophages: insights into bacteriophage evolution. Res Microbiol. 2008;159:332-9. https://doi.org/10.1016/j.resmic.2008.04. 008.

98. Petrovski S, Dyson ZA, Seviour RJ, Tillett D. Small but sufficient: the rhodococcus phage $\mathrm{RRH} 1$ has the smallest known siphoviridae genome at 14.2 kilobases. J Virol. 2012;86:358-63. https://doi.org/10. 1128/JVI.05460-11.

99. Yuan L, Hensley C, Mahsoub HM, Ramesh AK, Zhou P. Microbiota in viral infection and disease in humans and farm animals. In: Progress in molecular biology and translational science. 2020. p. 15-60. https://doi.org/10.1016/bs.pmbts.2020.04.005.

100. Rinninella E, Raoul P, Cintoni M, Franceschi F, Miggiano G, Gasbarrini A, et al. What is the healthy gut microbiota composition? A changing ecosystem across age, environment, diet, and diseases. Microorganisms. 2019;7:14. https://doi.org/10.3390/microorganisms7010014.

101. Li B, Yang Y, Ma L, Ju F, Guo F, Tiedje JM, et al. Metagenomic and network analysis reveal wide distribution and co-occurrence of environmental antibiotic resistance genes. ISME J. 2015;9:2490-502. https://doi.org/10.1038/ismej.2015.59.

102. Howard-Varona C, Hargreaves KR, Abedon ST, Sullivan MB. Lysogeny in nature: mechanisms, impact and ecology of temperate phages. ISME J. 2017;11:1511-20. https://doi.org/10.1038/ismej.2017.16. 
103. Sausset R, Petit MA, Gaboriau-Routhiau V, De Paepe M. New insights into intestinal phages. Mucosal Immunol. 2020;13:205-15. https:// doi.org/10.1038/s41385-019-0250-5.

104. City of Winnipeg. Sewage treatment plants Sewage treatment plants North End Sewage Treatment Plant ( NEWPCC) South End Sewage Treatment Plant (SEWPCC). 2020. https://winnipeg.ca/waterandwa ste/sewage/treatmentPlant/default.stm.

105. Auerbach EA, Seyfried EE, McMahon KD. Tetracycline resistance genes in activated sludge wastewater treatment plants. Water Res. 2007:41:1143-51.

106. City of Winnipeg. Biosolids Land Application Timeline. 2019. https:// winnipeg.ca/waterandwaste/publicengagement/biosolids-land-appli cation/default.stm.

\section{Publisher's Note}

Springer Nature remains neutral with regard to jurisdictional claims in published maps and institutional affiliations.

- fast, convenient online submission

- thorough peer review by experienced researchers in your field

- rapid publication on acceptance

- support for research data, including large and complex data types

- gold Open Access which fosters wider collaboration and increased citations

- maximum visibility for your research: over 100M website views per year

At BMC, research is always in progress.

Learn more biomedcentral.com/submissions 